Article

\title{
Energy, Exergy, Economic, and Exergoenvironmental Analyses of a Novel Hybrid System to Produce Electricity, Cooling, and Syngas
}

\author{
Saeed Esfandi ${ }^{1}$, Simin Baloochzadeh ${ }^{2, *}$, Mohammad Asayesh ${ }^{3}$, Mehdi Ali Ehyaei ${ }^{4}$, \\ Abolfazl Ahmadi ${ }^{5}$ D, Amir Arsalan Rabanian ${ }^{6}$, Biplab Das ${ }^{7}$, Vitor A. F. Costa ${ }^{8}$ (D) \\ and Afshin Davarpanah ${ }^{9, *}$ \\ 1 School of Urban Planning, College of Fine Arts, University of Tehran, Tehran 1417466191, Iran; \\ Esfandi_saeed@ut.ac.ir \\ 2 Faculty of Technology, University of Sunderland, Sunderland SR1 3SD, UK \\ 3 Department of Energy Engineering, Faculty of Natural Resources and Environment, \\ Science and Research Branch, Islamic Azad University, Tehran 1477893855, Iran; \\ mohammad.asayesh@srbiau.ac.ir \\ 4 Department of Mechanical Engineering, Pardis Branch, Islamic Azad University, \\ Pardis New City 1468995513, Iran; aliehyaei@pardisiau.ac.ir \\ 5 Department of Energy Systems Engineering, School of New Technologies, \\ Iran University of Science and Technology, Tehran 1584743311, Iran; a_ahmadi@iust.ac.ir \\ 6 School of Environment, College of Engineering, University of Tehran, Tehran 1417466191, Iran; \\ A.rabanian@ut.ac.ir \\ 7 Department of Mechanical Engineering, National Institute of Technology Silchar, Asaam 788010, India; \\ bpd@mech.nits.ac.in \\ 8 Center for Mechanical Technology and Automation, Department of Mechanical Engineering, \\ University of Aveiro, 3810-193 Aveiro, Portugal; v.costa@ua.pt \\ 9 Department of Mathematics, Aberystwyth University, Aberystwyth SY23 3FL, UK \\ * Correspondence: bg17pm@student.sunderland.ac.uk (S.B.); afd6@aber.ac.uk (A.D.)
}

Received: 13 October 2020; Accepted: 3 December 2020; Published: 6 December 2020

\begin{abstract}
Efficient solar and wind energy to electricity conversion technologies are the best alternatives to reduce the use of fossil fuels and to evolve towards a green and decarbonized world. As the conventional photovoltaic systems use only the $600-1100 \mathrm{~nm}$ wavelength range of the solar radiation spectrum for electricity production, hybrid systems taking advantage of the overall solar radiation spectrum are gaining increasing interest. Moreover, such hybrid systems can produce, in an integrated and combined way, electricity, heating, cooling, and syngas through thermochemical processes. They have thus the huge potential for use in residential applications. The present work proposes a novel combined and integrated system for residential applications including wind turbines and a solar dish collector for renewables energy harvesting, an organic Rankine cycle for power production, an absorption chiller for cold production, and a methanation plant for $\mathrm{CH}_{4}$ production from captured $\mathrm{CO}_{2}$. This study deals with the energy, exergy, economic, and exergoenvironmental analyses of the proposed hybrid combined system, to assess its performance, viability, and environmental impact when operating in Tehran. Additionally, it gives a clear picture of how the production pattern of each useful product depends on the patterns of the collection of available renewable energies. Results show that the rate of methane production of this hybrid system changes from 42 up to $140 \mathrm{Nm}^{3} / \mathrm{month}$, due to $\mathrm{CO}_{2}$ consumption from 44 to $144 \mathrm{Nm}^{3} /$ month during a year. Moreover, the energy and exergy efficiencies of this hybrid system vary from $24.7 \%$ and $23 \%$ to $9.1 \%$ and $8 \%$, respectively. The simple payback period of this hybrid system is 15.6 and the payback period of the system is 21.4 years.
\end{abstract}


Keywords: solar dish; Organic Rankine Cycle; absorption chiller; wind turbine; energy and exergy analysis; economic analysis

\section{Introduction}

Increasing energy demand, fossil fuel depletion, and environmental concerns with the use of fossil fuels drive the present society towards renewable energy use [1-5]. Abundant in nature and renewable, solar energy has been increasingly used in recent decades [3,6-8]. However, the efficiency of solar to electricity conversion technologies is still a concern for a promising future [9-12]. Thus, hybrid systems utilizing all ranges of solar radiation spectrum are gaining popularity for electricity, heating, cooling, and solar fuel production through thermoschemical processes [13-15]. Moreover, several studies have been performed to show that the multigeneration systems are capable of energy production in comparison to standalone configurations [16-18]. Organic Rankine Cycle (ORC) power systems are proved to be one of the promising technologies for the exploitation of low-temperature energy sources [19].

Wang et al. [20] reported the experimental analysis of a solar-based organic Rankine cycle (ORC) having both flat plates and evacuated tube-based collectors for low-temperature applications. The obtained results of this system revealed an isentropic efficiency of $45.2 \%$, providing a mechanical power output of $1.73 \mathrm{~kW}$.

Wang et al. [21] studied flat plate collectors with an ORC cycle for three conditions including power generation, combined heat, and power (CHP) and combined cooling and power (CCP) model. The results showed the maximum power generation of this system is in the power mode and CHP mode. Wang et al. [22] examined an energy optimization of a flat plate solar collector with an ORC for the combined generation of cooling, heating, and power (multigeneration system). NSGA-II algorithm was applied to optimize the total heat transfer area and the power production.

Calise et al. [23] reported the performance of a hybrid system based on solar energy, geothermal energy, and an auxiliary boiler, for the combined production of cooling, heating, power, and freshwater purposes. The results of this study demonstrated the maximum exergy efficiencies of about $50 \%$ and $20 \%$, when operating in the heating and cooling mode, respectively.

Bellos and Tzivanidis [24] reported examination of an ORC based hybrid system with an ejector device, with $87 \%$ and $12 \%$ energy and exergy efficiencies, respectively. Gogoi and Saikia [25] studied a combined system having a solar-based ORC cycle and an absorption cooling system, considering five different working fluids for the environmental conditions of Jaipur, India. They concluded that the system provided a net power up to $1.7 \mathrm{MW}$ in February with R245fa as the working fluid, and a maximum cooling of 6.0 MW was obtained with Neopentane.

El-Emam and Dincer [26] examined a hybrid system driven by solar energy and biomass to produce hydrogen, electricity, and supply cooling. The outcome of this study showed the energy and exergy efficiencies of $40 \%$ and $27 \%$, respectively for this hybrid system. Khalid et al. [27] investigated a hybrid system using biomass to supply power, hot water, and space cooling/heating. They report thermal and exergy efficiencies of $91 \%$ and $35 \%$ for this cogeneration system, respectively.

El-Emam and Dincer [28] examined a novel hybrid system consisting of a solar tower, a Rankine power cycle, an electrolyzer, a desalination unit, and an absorption chiller. The proposed system supplied cooling, heating, and power; moreover, it was capable of freshwater and hydrogen production. They reported the maximum energy and exergy efficiencies were $40 \%$ and $30 \%$, respectively. Utilization of waste heat of photovoltaic/thermal (PV/T) systems in a thermoelectric-based electrolyzer for hydrogen production was proposed by Behzadi et al. [29]. The exergy efficiency of up to $12.01 \%$ was obtained for this system. 
Moaleman et al. [30] proposed a system that produces power and heating by the integration of thermal collectors and a linear Fresnel reflector. The results revealed the yearly production of cooling, heating, and power generation of 3944, 6528, and $2290 \mathrm{kWh}$, respectively for this system.

Exergoenvironmental analysis of any power system to evaluate the exergy-based cost of unit power is recent, and most of the previous studies on hybrid systems have not been paid much attention to it. A detailed exergoeconomic and exergoenvironmental analysis of a solar combined cycle system by Cavalcanti [31] indicated that the solar field could help to increase the electricity production by $4.2 \%$, reduce the costs production by $2.6 \%$, and decrease the exergy based environmental impact by $3.8 \%$. Table 1 summarizes the key points of each research.

Table 1. The summary of key point of each research.

\begin{tabular}{|c|c|c|c|c|}
\hline No. & Authors & Ref & System & Key Points \\
\hline 1 & Wang et al. & [20] & R245a ORC solar powered & $\begin{array}{c}\text { The electrical power production is } \\
\text { equal } 1.73 \mathrm{~kW} \text { with } 45.2 \% \\
\text { isentropic efficiency }\end{array}$ \\
\hline 2 & Wang et al. & [21] & $\begin{array}{l}\text { Solar powered ORC and ejector } \\
\text { refrigeration cycle to produce } \\
\text { power, heating, and cooling }\end{array}$ & $\begin{array}{c}\text { For the CCP and CHP modes, } \\
\text { the optimum average output was } \\
5.84,8.89 \mathrm{~kW} \text {, respectively. }\end{array}$ \\
\hline 3 & Wang et al. & [22] & $\begin{array}{l}\text { Solar powered triple cycle to } \\
\text { produce electrical power, heating, } \\
\text { and cooling }\end{array}$ & $\begin{array}{l}\text { The system efficiency in CHP, } \\
\text { CCP, and power modes is equal to } \\
19.10 \%, 27.24 \% \text {, and } 10.47 \% \text {, } \\
\text { respectively. }\end{array}$ \\
\hline 4 & Calise et al. & [23] & $\begin{array}{c}\text { Solar powered ORC, } \\
\text { and multieffect distillation, } \\
\text { absorption chiller to produce } \\
\text { electrical power, heating, cooling, } \\
\text { and fresh water }\end{array}$ & $\begin{array}{l}\text { The exergy efficiency is between } \\
40 \% \text { and } 50 \% \text { during the thermal } \\
\text { recovery operation and it is } \\
\text { between } 16 \% \text { and } 20 \% \text { during the } \\
\text { cooling operation. }\end{array}$ \\
\hline 5 & $\begin{array}{l}\text { Bellos and } \\
\text { Tzivanidis }\end{array}$ & [24] & $\begin{array}{c}\text { The ORC based hybrid system } \\
\text { with an ejector device }\end{array}$ & $\begin{array}{l}\text { The optimum system energy and } \\
\text { exergy efficiencies are equal to } \\
87 \% \text { and } 12 \%\end{array}$ \\
\hline 6 & $\begin{array}{l}\text { Gogoi and } \\
\text { Saikia }\end{array}$ & [25] & $\begin{array}{l}\text { Solar powered ORC with } \\
\text { absorption chiller }\end{array}$ & $\begin{array}{l}\text { Maximum power is produced } \\
(1.74 \mathrm{MW}) \text { by the } \mathrm{R} 245 \mathrm{fa} \text { and the } \\
\text { minimum value }(1.62 \mathrm{MW}) \text { with } \\
\text { Neo-pentane }\end{array}$ \\
\hline 7 & $\begin{array}{l}\text { El-Emam and } \\
\text { Dincer }\end{array}$ & [26] & $\begin{array}{c}\text { The helium cycle and SOFC } \\
\text { powered by solar and } \\
\text { biomass energy }\end{array}$ & $\begin{array}{l}\text { The system energy and exergy } \\
\text { efficiencies are } 39.9 \% \text { and } 27.5 \%\end{array}$ \\
\hline 8 & Khalid et al. & [27] & $\begin{array}{c}\text { ORC, gas cycle, } \\
\text { and absorption chiller }\end{array}$ & $\begin{array}{l}\text { The system energy and exergy } \\
\text { efficiencies are } 91.0 \% \text { and } 34.9 \% \text {, } \\
\text { respectively. The levelized cost of } \\
\text { electricity is } \$ 0.117 / \mathrm{kW} \mathrm{h} \text {. }\end{array}$ \\
\hline 9 & $\begin{array}{l}\text { El-Emam and } \\
\text { Dincer }\end{array}$ & [28] & $\begin{array}{l}\text { Heliostat solar receiver and } \\
\text { steam cycle }\end{array}$ & $\begin{array}{c}\text { This system produces } 4 \mathrm{MW} \\
\text { electric power, } 1.25 \mathrm{~kg} / \mathrm{h} \text { of } \\
\text { hydrogen, and } 90 \mathrm{~kg} / \mathrm{s} \text { of fresh } \\
\text { water }\end{array}$ \\
\hline 10 & Behzadi et al. & [29] & $\begin{array}{l}\text { Photovoltaic/thermal cells and } \\
\text { thermoelectric generator }\end{array}$ & $\begin{array}{l}\text { The exergy efficiency and total } \\
\text { cost rate reach } 12.01 \% \text { and } \\
0.1762 \$ / \mathrm{h}\end{array}$ \\
\hline 11 & Moaleman et al. & [30] & $\begin{array}{c}\text { Concentrating } \\
\text { photovoltaic-thermal unit and } \\
\text { water-ammonia absorption chiller }\end{array}$ & $\begin{array}{l}\text { The system trigeneration energy } \\
\text { efficiency reaches } 58.01 \%\end{array}$ \\
\hline
\end{tabular}


Pertinent literature reveals that attempts have been made to design, develop, and analyze hybrid systems using carbon-free renewable energy sources for cooling, heating, and power (CHP). Further, a few applications were also coupled with the CHP system to produce freshwater, hydrogen, and in limited cases syngas. The present proposed system goes also in the direction of the increasing use of renewable energy sources. However, limited studies existed in literature about the combined use of solar and wind energy sources in Ref. [32], but the production of syngas from the combination of renewable energy sources has not been investigated yet. Further, in most of the previous studies, systems' efficiency was limited to energy and exergy only. The addition of economic and exergoenvironmental assessment of the proposed hybrid system gives additional relevance to this study. The system under consideration is said to be hybrid as it is based on a combination of renewable energy sources. The innovations of this research are as follows:

- Developing the new hybrid system consisting of the solar and wind energy resources

- Producing electricity, cooling, and syngas by this hybrid cogeneration system

- Energy, exergy, economic, and exergoenvironmental (4E) analyses

\section{Mathematical Modeling}

\subsection{System and Process Description}

Figure 1 is a schematic diagram of the proposed system, the arrows also illustrating the process. The proposed system comprises six subsystems: solar dish, ORC, single-effect absorption chiller, proton-exchange membrane (PEM) electrolyzer, wind turbine, and methanation plant. The working fluids in the solar dish, ORC, and absorption chiller subsystems are Terminol VP-1, R134a, and lithium bromide solution, respectively. Terminol VP-1 is capable of operating under pressures of $15 \mathrm{bar}$ and temperatures up to $400{ }^{\circ} \mathrm{C}$ [33]. R134a exhibits the highest energy and exergy efficiencies for the ORC system [33-35]. Water, as a refrigerant and lithium bromide as an absorbent, is one of the most used working fluid pairs in the absorption chillers [36].

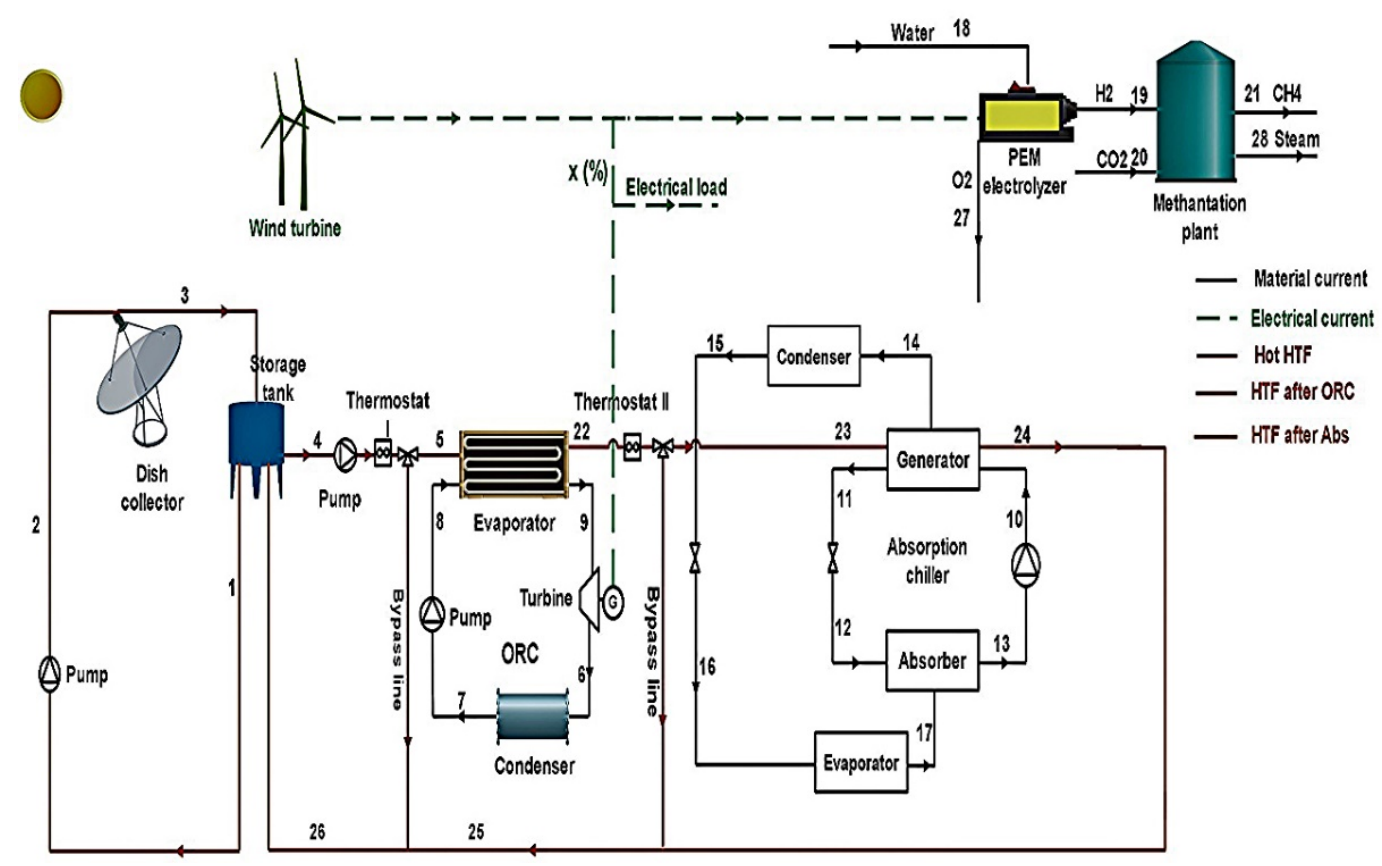

Figure 1. The schematic diagram of the system.

Terminol VP-1 passes through a solar dish collector to absorb the solar radiation heat (1). A thermal energy storage tank is used to attenuate the fluctuations of solar radiation and for the system's operating even during the night and to the operating fluid reach the desired temperature. The thermostat I 
avoids sending the Terminol at temperatures lower than $80^{\circ} \mathrm{C}$ to the ORC's evaporator. When the Terminol temperature is under $80^{\circ} \mathrm{C}$, it can be pumped through the bypass line back to the storage tank, and when it is over $80^{\circ} \mathrm{C}$ it is pumped to the evaporator (2) of the ORC subsystem to heat the ORC working fluid. The superheated R134a enters the turbine (9) to generate power, then it passes through the condenser and it is pumped back to the evaporator to close the ORC. The electricity produced from the ORC subsystem provides part of the electricity needs in the methanation subsystem; the remaining electricity can be used to supply the electric loads or even sent to the electric grid. Thermostat II avoids sending the Terminol at temperatures lower than $60^{\circ} \mathrm{C}$ to the absorption chiller's generator. When the Terminol temperature is under $60^{\circ} \mathrm{C}$, it is sent back through a bypass line to the storage tank, and when its temperature is over $60^{\circ} \mathrm{C}$ it enters the absorption chiller's generator (3) to provide the heat required for the cooling products in the evaporator.

Wind turbines produce part of the electricity required by the electrolyzer. The hydrogen produced in the electrolyzer enters the methanation plant (19), where it reacts with supplied $\mathrm{CO}_{2}$ (A2) to produce $\mathrm{CH}_{4}$ syngas (A3) and steam (A4). In this way, the syngas (that has many useful applications) production is fully based on renewable sources. Besides that, cooling and power are produced simultaneously by absorption chiller, ORC, and wind turbines, respectively. Additionally, the heat released by the condenser of the absorption chiller and by the ORC condenser, oxygen released by the electrolyzer, and steam released by the methanation plant can be useful for any purpose.

The following main assumptions are considered in the system's modeling and simulation:

- The storage tank is used to attenuate some small system fluctuations, and it is assumed that along a day the HTF conditions when leaving the storage tank are the same as the HTF leaving the solar dish [37,38].

- Ambient pressure and temperature are $1 \mathrm{~atm}$ and $15^{\circ} \mathrm{C}[39]$

- The Weibull distribution density function is assumed for the wind speed in wind turbine power production [40]

- The dish collector is assumed to be always directed to the sun

- The efficiency of the ORC turbine and pumps are considered to be $85 \%[39,41]$

- For the heat exchanging components such as the condenser and the evaporator, energy effectiveness is assumed to be $85 \%[1,39]$

- The Terminol pressure loss is presumed to be $3 \%$ through the pipe $[1,39]$

- Heat loss of components is assumed around 3\% of the energy released by the hottest steam at these components [1,39]

The solar radiation and wind turbine modelling are presented in Appendix A.

\subsection{Mass and Energy Balances}

The following reaction occurs in the electrolyzer for water splitting [42]:

$$
\mathrm{H}_{2} \mathrm{O}(\mathrm{l})+\text { electrical energy } \rightarrow \mathrm{H}_{2}(\mathrm{~g})+\frac{1}{2} \mathrm{O}_{2}(\mathrm{~g})
$$

The performance of the electrolyzer can be obtained from the following equation [42-44]:

$$
\eta_{\mathrm{V}}=\frac{1.25}{\mathrm{~V}_{\text {elec }}}
$$

As the voltage efficiency of the PEM is assumed to be $72 \%$, an operational voltage of $1.74 \mathrm{~V}$ is achieved. The mass flow rate of the produced hydrogen can be expressed as [42-44]:

$$
\dot{\mathrm{m}}_{\mathrm{H} 2}=\frac{\dot{\mathrm{W}}_{\text {elec }}}{\mathrm{V}_{\text {elec }} * \mathrm{~F}}
$$


where F represents the Faraday's constant, 96,495 C/mole, and subscript elec denotes electrolyzer [42-44].

The reaction that happens in the methanation plant can be expressed as:

$$
\mathrm{CO}_{2}+4 \mathrm{H}_{2} \leftrightarrow \mathrm{CH}_{4}+2 \mathrm{H}_{2} \mathrm{O}
$$

The Coefficient of Performance (COP) of the absorption chiller is defined as:

$$
\mathrm{COP}=\frac{\dot{\mathrm{Q}}_{\mathrm{Eva}}}{\dot{\mathrm{Q}}_{\mathrm{Gen}}+\dot{\mathrm{W}}_{\mathrm{P}}}
$$

where subscripts Eva, Gen, and p denote evaporator, generator, and chiller's pump.

Mass and energy balances and energy efficiencies for each component of the proposed system are summarized in Table $2[34,40,41,45-47]$.

\begin{tabular}{|c|c|c|}
\hline Component & Mass Balance Equation & Energy Balance Equation \\
\hline \multicolumn{3}{|c|}{ Solar dish } \\
\hline Dish collector & $\dot{\mathrm{m}}_{2}=\dot{\mathrm{m}}_{3}$ & $\dot{\mathrm{m}}_{2} \mathrm{c}_{\mathrm{p}}\left(\mathrm{T}_{3}-\mathrm{T}_{2}\right)=\eta_{\mathrm{th}} \dot{\mathrm{Q}}_{\mathrm{S}}$ \\
\hline Pump & $\dot{\mathrm{m}}_{1}=\dot{\mathrm{m}}_{2}$ & $\dot{\mathrm{W}}_{\mathrm{p}}=\frac{\dot{\mathrm{m}}_{1}\left(\mathrm{~h}_{2 \mathrm{~s}}-\mathrm{h}_{1}\right)}{\eta_{\mathrm{p}}}$ \\
\hline \multicolumn{3}{|c|}{ Absorption chiller } \\
\hline Pump & $\dot{\mathrm{m}}_{13}=\dot{\mathrm{m}}_{10}$ & $\dot{\mathrm{W}}_{\mathrm{p}}=\frac{\dot{\mathrm{m}}_{13}\left(\mathrm{~h}_{10 \mathrm{~s}}-\mathrm{h}_{13}\right)}{\eta_{\mathrm{P}}}$ \\
\hline Expansion valve 1 & $\dot{\mathrm{m}}_{15}=\dot{\mathrm{m}}_{16}$ & $\mathrm{~h}_{15}=\mathrm{h}_{16}$ \\
\hline Absorber & $\dot{\mathrm{m}}_{12}+\dot{\mathrm{m}}_{17}=\dot{\mathrm{m}}_{13}$ & $\dot{\mathrm{m}}_{17} \mathrm{~h}_{17}+\dot{\mathrm{m}}_{12} \mathrm{~h}_{12}=\dot{\mathrm{m}}_{13} \mathrm{~h}_{13}+\dot{\mathrm{Q}}_{\mathrm{A}}$ \\
\hline Generator & $\dot{\mathrm{m}}_{11}+\dot{\mathrm{m}}_{14}=\dot{\mathrm{m}}_{10}$ & $\dot{\mathrm{m}}_{10} \mathrm{~h}_{10}+\dot{\mathrm{m}}_{23} \mathrm{~h}_{23}=\dot{\mathrm{m}}_{11} \mathrm{~h}_{11}+\dot{\mathrm{m}}_{14} \mathrm{~h}_{14}+\dot{\mathrm{m}}_{24} \mathrm{~h}_{24}+\dot{\mathrm{Q}}_{\mathrm{G}}$ \\
\hline Condenser & $\dot{\mathrm{m}}_{15}=\dot{\mathrm{m}}_{14}$ & $\dot{\mathrm{Q}}_{\mathrm{C}}=\dot{\mathrm{m}}_{14}\left(\mathrm{~h}_{14}-\mathrm{h}_{15}\right)$ \\
\hline Expansion valve 2 & $\dot{\mathrm{m}}_{11}=\dot{\mathrm{m}}_{12}$ & $\mathrm{~h}_{11}=\mathrm{h}_{12}$ \\
\hline Evaporator & $\dot{\mathrm{m}}_{16}=\dot{\mathrm{m}}_{17}$ & $\dot{\mathrm{Q}}_{\mathrm{E}}=\dot{\mathrm{m}}_{16}\left(\mathrm{~h}_{17}-\mathrm{h}_{16}\right)$ \\
\hline \multicolumn{3}{|c|}{ ORC } \\
\hline Pump & $\dot{\mathrm{m}}_{8}=\dot{\mathrm{m}}_{7}$ & $\dot{\mathrm{W}}_{\mathrm{p}}=\frac{\dot{\mathrm{m}}_{\mathrm{ORC}}\left(\mathrm{h}_{8 \mathrm{~s}}-\mathrm{h}_{7}\right)}{\eta_{\mathrm{p}}}$ \\
\hline Evaporator & $\dot{\mathrm{m}}_{8}=\dot{\mathrm{m}}_{9}$ and $\dot{\mathrm{m}}_{5}=\dot{\mathrm{m}}_{22}$ & $\dot{\mathrm{Q}}_{\mathrm{E}}=\dot{\mathrm{m}}_{\mathrm{ORC}}\left(\mathrm{h}_{9}-\mathrm{h}_{8}\right)=\dot{\mathrm{m}}_{\mathrm{HTF}}\left(\mathrm{h}_{5}-\mathrm{h}_{22}\right)$ \\
\hline Turbine & $\dot{\mathrm{m}}_{6}=\dot{\mathrm{m}}_{9}$ & $\dot{\mathrm{W}}_{\mathrm{T}}=\dot{\mathrm{m}}_{\mathrm{ORC}}\left(\mathrm{h}_{9}-\mathrm{h}_{6 \mathrm{~s}}\right) \eta_{\mathrm{T}}$ \\
\hline Condenser & $\dot{\mathrm{m}}_{6}=\dot{\mathrm{m}}_{7}$ & $\dot{\mathrm{Q}}_{\mathrm{C}}=\dot{\mathrm{m}}_{\mathrm{ORC}}\left(\mathrm{h}_{6}-\mathrm{h}_{7}\right)$ \\
\hline \multicolumn{3}{|c|}{ PEM } \\
\hline PEM electrolyzer & $\dot{\mathrm{m}}_{18}=\dot{\mathrm{m}}_{27}+\dot{\mathrm{m}}_{19}$ & $\dot{\mathrm{m}}_{18} \mathrm{~h}_{18}+\dot{\mathrm{W}}_{\text {elec }}=\dot{\mathrm{m}}_{27} \mathrm{~h}_{27}+\dot{\mathrm{m}}_{19} \mathrm{~h}_{19}$ \\
\hline \multicolumn{3}{|c|}{ Wind turbines } \\
\hline Wind turbine & - & $\begin{array}{c}\dot{\mathrm{W}}_{\text {wind,ave }}= \\
\dot{\mathrm{W}}_{\text {wind,er }}\left[\frac{\exp \left(-\left(\frac{\mathrm{u}_{\mathrm{c}}}{\mathrm{C}}\right)\right)^{\mathrm{K}}-\exp \left(-\left(\frac{\mathrm{u}_{\mathrm{r}}}{\mathrm{C}}\right)\right)^{\mathrm{K}}}{\left(\frac{\mathrm{u}_{\mathrm{r}}}{\mathrm{C}}\right)^{\mathrm{K}}-\left(\frac{\mathrm{u}_{\mathrm{c}}}{\mathrm{C}}\right)^{\mathrm{K}}}-\exp \left(-\left(\frac{\mathrm{u}_{\mathrm{f}}}{\mathrm{C}}\right)\right)^{\mathrm{K}}\right]\end{array}$ \\
\hline \multicolumn{3}{|c|}{ Methanation plant } \\
\hline Methanation plant & $\dot{\mathrm{m}}_{19}+\dot{\mathrm{m}}_{20}=\dot{\mathrm{m}}_{21}+\dot{\mathrm{m}}_{28}$ & $\dot{\mathrm{m}}_{19} \mathrm{~h}_{19}+\dot{\mathrm{m}}_{20} \mathrm{~h}_{20}=\dot{\mathrm{m}}_{21} \mathrm{~h}_{21}+\dot{\mathrm{m}}_{28} \mathrm{~h}_{28}$ \\
\hline
\end{tabular}

Table 2. Mass and energy balance equations and energy efficiency of the system's components. 
In Table $1, \mathrm{~T}, \mathrm{~h}, \mathrm{c}_{\mathrm{p}}$, and $\dot{\mathrm{m}}$ denote temperature, specific enthalpy, constant pressure specific heat, and mass flow rate, respectively. $\dot{W}$ and $\dot{Q}$ represent power and heat transfer rates. $\eta$ is polythrophic efficiency. Subscripts E, T, C, and elec refer to evaporator, turbine, condenser, and electrolyzer, respectively. HHV stands for the higher heating value.

The energy efficiency of the whole system can be set as:

$$
\text { Energy efficiency }=\frac{\dot{\mathrm{W}}_{\mathrm{T}}+\dot{\mathrm{W}}_{\text {windturbine,ave }}-\dot{\mathrm{W}}_{\mathrm{p}}-\dot{\mathrm{W}}_{\text {elec }}+\dot{\mathrm{m}}_{21} \mathrm{HHV}_{\mathrm{CH}_{4}}+\dot{\mathrm{Q}}_{\mathrm{E}}}{\mathrm{A}_{\mathrm{a}} \mathrm{G}_{\mathrm{b}}+\dot{\mathrm{W}}_{\text {windturbine,er }}}
$$

where subscripts E, T, P, and elec refer to the evaporator of the absorption chiller, turbine of the ORC, pumps, and electrolyzer, respectively. The energy efficiency of the whole system is the ratio between the useful energy effect of the system and the energy input required to drive it (even if it uses only renewable energy sources). The energy inputs are solar and wind energy and useful outputs are cooling at the evaporator of the absorption chiller, electricity, and produced syngas methane.

\subsection{Exergy Balance}

Exergy analysis is a powerful tool to identify inefficiencies of industrial processes and to improve them. Exergy comprises thermomechanical and chemical components, and it is the maximum amount of useful work that can be achieved by a system when it evolves up to reach equilibrium with the environment.

The total specific exergy of a stream is expressed as [48]:

$$
\mathrm{ex}=\left(\mathrm{h}-\mathrm{h}_{0}\right)-\mathrm{T}_{0}\left(\mathrm{~s}-\mathrm{s}_{0}\right)+\mathrm{T}_{0} \sum \mathrm{x}_{\mathrm{i}} \mathrm{R}_{\mathrm{i}} \ln \mathrm{y}_{\mathrm{i}}+\sum \mathrm{x}_{\mathrm{i}} \mathrm{ex}_{\text {chi }}+\frac{\mathrm{V}^{2}}{2}+\mathrm{gz}
$$

where $h$ and $T$ are enthalpy and absolute temperature, and $R_{i}$ is the particular gas constant of chemical species $i . x_{i}$ and $y_{i}$ denote the mass fraction and mole fraction of chemical species $i$, ex $x_{c h i}$ is the specific chemical exergy of chemical species $i$. and $z, g$, and $v$ are height, gravitational acceleration, and velocity, respectively. The subscript i denotes chemical species $i$, and 0 refers to the environment condition (dead state).

Potential and kinetic exergy changes can be assumed negligible. Table 3 summarizes the exergy efficiency and the exergy destruction rate ( $\left.\dot{\mathrm{E}}_{\mathrm{D}}\right)$ for each component of the proposed system [49-54].

Where, for wind turbine equations, $\rho$ represents the air density, $A_{2}$ denotes the swept area of the wind turbine, and $\mathrm{u}$ is the wind velocity as mentioned above.

The whole system exergy efficiency can be obtained as:

$$
\text { Exergy efficiency }=\frac{\dot{\mathrm{W}}_{\mathrm{T}}-\dot{\mathrm{W}}_{\mathrm{p}}+\dot{\mathrm{W}}_{\text {windturbine,ave }}-\dot{\mathrm{W}}_{\text {elec }}+\dot{\mathrm{m}}_{21} \mathrm{ex}_{21}-\dot{\mathrm{Q}}_{\mathrm{E}}\left(1-\frac{\mathrm{T}_{0}}{\mathrm{~T}_{\mathrm{E}}}\right)}{\mathrm{A}_{\mathrm{a}} \mathrm{G}_{\mathrm{b}}\left(1-\frac{4}{3}\left(\frac{\mathrm{T}_{\mathrm{amb}}}{\mathrm{T}_{\text {sun }}}\right)+\frac{1}{3}\left(\frac{\mathrm{T}_{\mathrm{amb}}}{\mathrm{T}_{\text {sun }}}\right)^{4}\right)+\dot{\mathrm{W}}_{\text {windturbine,er }}}
$$

where subscripts E, T, P, amb, 0 denote evaporator of the chiller, turbine, pumps, ambient, and dead state condition, respectively. The exergy efficiency is defined as the ratio between the useful exergy output from the system and the needed exergy input. Similar to energy efficiency, the inputs of the system are solar and wind energy and outputs are cooling at the evaporator of the absorption chiller, electricity, and produced syngas methane. 
Table 3. Exergy efficiency and exergy destruction rate for each component of the proposed system.

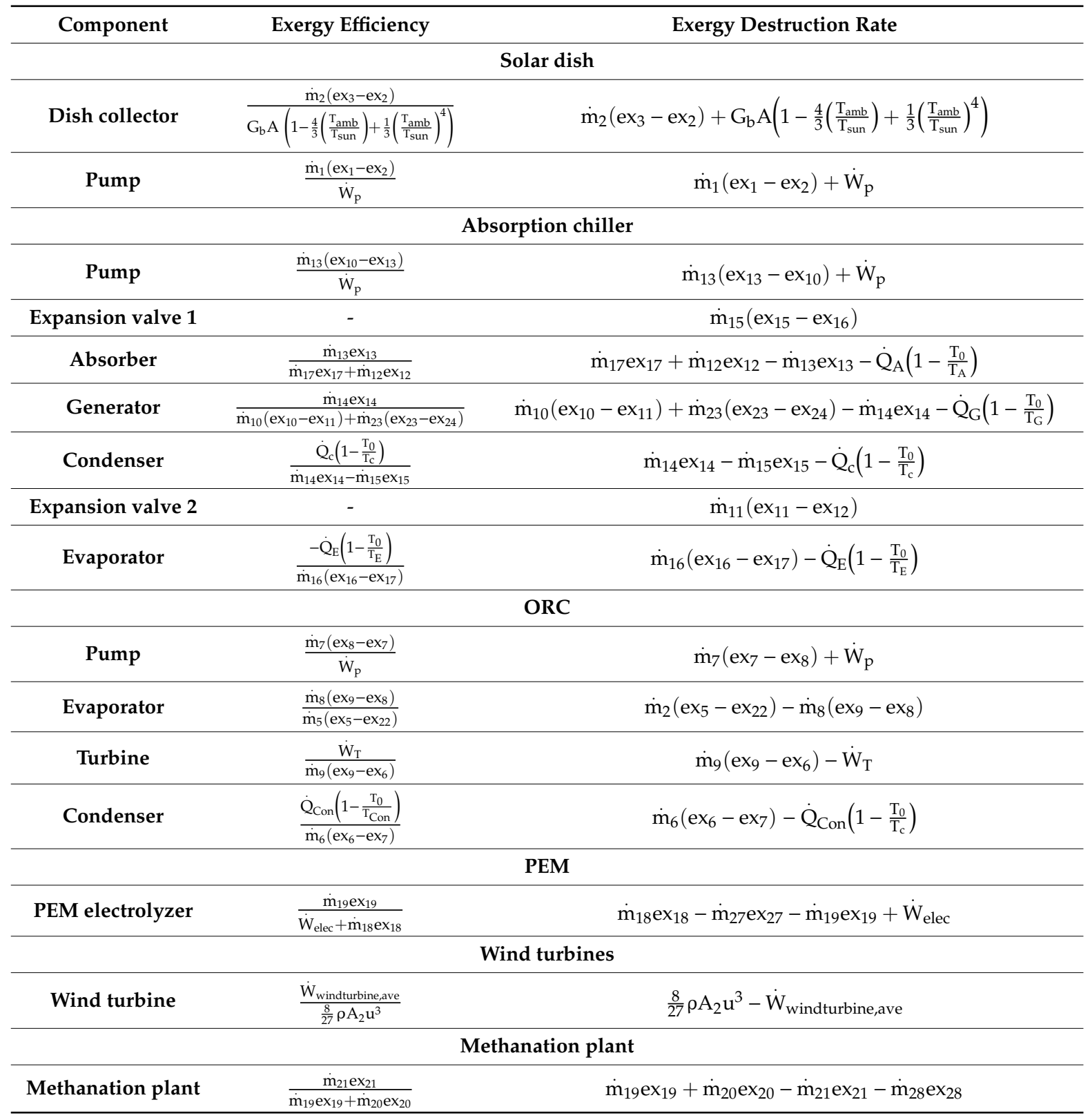

\subsection{Economic Analysis}

Financial analysis can provide a valuable point of view about the capital investment cost, payback period, and the system's income cash flow. Therefore, this assessment plays a key role to bring an understanding of the financial supports and outcome of the energy system to policymakers, decision-makers, and investors. Each of the following indices is necessary to have a proper economic understanding of a system.

The total investment cost, $\mathrm{C}_{0}$, is obtained as [55,56]:

$$
\mathrm{C}_{0}=\mathrm{K}_{\text {Solar dish }}+\mathrm{K}_{\text {Absorption chiller }}+\mathrm{K}_{\text {Methanation }}+\mathrm{K}_{\mathrm{Elec}}+\mathrm{K}_{\mathrm{ORC}}
$$

where subscripts refer to the main subsystems, and K denote the investment cost of each subsystem, which are listed in Table 4, where T, P, A, and E represent the turbine, pump, surface area of the heat exchanger, and evaporator of an absorption chiller, respectively. 
Table 4. Cost of purchase and installation of the system's components.

\begin{tabular}{ccc}
\hline Component & Cost Function (\$) & Source (s) \\
\hline Turbine & $2237\left(\dot{\mathrm{W}}_{\mathrm{T}}\right)^{0.41}$ & {$[57]$} \\
\hline Pump & $1026\left(\frac{\mathrm{W}_{\mathrm{p}}}{300}\right)^{0.25}$ & {$[58]$} \\
\hline Condenser & $0338.6 \mathrm{~A}$ & {$[58]$} \\
\hline Evaporator & $216.6+353.4 \mathrm{~A}$ & {$[58,59]$} \\
\hline & Absorption chiller & {$[60]$} \\
\hline Absorption chiller & $14,740.2095$ & {$[61]$} \\
\hline Wind turbine & $\left(\dot{\mathrm{Q}}_{\mathrm{E}}\right)^{-0.6849}+3.29$ & {$[55,56]$} \\
\hline Solar dish & 53,000 & {$[55,56]$} \\
\hline Storage tank & 5650 & {$[62]$} \\
\hline Methanation & 2000 & {$[62]$} \\
\hline Electrolyzer & 500 & {$[55,56]$} \\
\hline Piping & 2260 & \\
\hline
\end{tabular}

The yearly income cash flow of the proposed system, denoted as CF, is expressed as [55,56]:

$$
\mathrm{CF}=\mathrm{Y}_{\text {electrical }} \mathrm{k}_{\text {electrical }}+\mathrm{Y}_{\text {cooling }} \mathrm{k}_{\text {cooling }}+\mathrm{Y}_{\mathrm{CH} 4} \mathrm{k}_{\mathrm{CH} 4}
$$

where $\mathrm{Y}$ represents the yearly energy parameter, and $\mathrm{k}$ is the specific cost of each of the products, as detailed in Table 5 .

Table 5. The specific cost of each product for financial analysis $[56,63]$.

\begin{tabular}{cc}
\hline Products of the System & Price $\left(\mathbf{\$} \mathbf{k W h}^{\mathbf{- 1}} \mathbf{)}\right.$ \\
\hline $\mathbf{k}_{\text {electrical }}$ & 0.22 \\
\hline $\mathbf{k}_{\text {cooling }}$ & 0.074 \\
\hline $\mathbf{k}_{\mathbf{C H} 4}$ & 0.093 \\
\hline
\end{tabular}

For the investment, the Internal Rate of Return (IRR) is obtained as [55,56]:

$$
\mathrm{IRR}=\frac{\mathrm{CF}}{\mathrm{C}_{0}}\left[1-\frac{1}{(1+\mathrm{IRR})^{\mathrm{N}}}\right]
$$

The Net Present Value (NPV) presents the total investment gain during the lifetime of the project, which can be expressed as [55,56]:

$$
\mathrm{NPV}=-\mathrm{C}_{0}+\mathrm{CF} \frac{(1+\mathrm{r})^{\mathrm{N}}-1}{\mathrm{r}(1+\mathrm{r})^{\mathrm{N}}}
$$

where $\mathrm{r}$ and $\mathrm{N}$ denote discount factor and project lifetime, here considered to be $3 \%$ and 25 years, respectively. The Simple Payback Period (SPP) can be obtained as [55,56]:

$$
\mathrm{SPP}=\frac{\mathrm{C}_{0}}{\mathrm{CF}}
$$


and the Payback Period (PP) equation is [55,56]:

$$
\mathrm{PP}=\frac{\ln \left(\frac{\mathrm{C}_{\mathrm{F}}}{\mathrm{CF}-\mathrm{r} \cdot \mathrm{C}_{0}}\right)}{\ln (1+\mathrm{r})}
$$

As it can be seen, each index is independent of the others and can be taken individually. Table 3 summarizes the cost of purchase and installation of the system's components, and Table 4 summarizes the electricity, cooling, and syngas prices.

\subsection{Exergoenvironment Analysis}

The exergoenvironment (exergy-environmental) study is a complement to the analysis of an energy system. This analysis clarifies the relationship between exergy destruction and environmental impact and highlights the effect of the system on the environment as caused by the system's inefficiencies. The smaller the impact factor is, the smaller is its environmental impact, which is achievable by reducing the system's exergy destruction rate.

The exergoenvironment factor is obtained as [64-66]:

$$
\mathrm{f}_{\mathrm{ei}}=\frac{\dot{\mathrm{E}} \mathrm{x}_{\text {tot,des }}}{\sum \dot{\mathrm{E}} \mathrm{x}_{\mathrm{in}}}
$$

where $\dot{E} x_{\text {tot,des }}$ and $\sum \dot{E} x_{\text {in }}$ denote, respectively, the overall exergy destruction rate and input of exergy into the system. For an energy system, the effectiveness factor of environmental damage can be evaluated as [64-66]:

$$
\theta_{\mathrm{ei}}=\mathrm{f}_{\mathrm{ei}} \cdot \mathrm{C}_{\mathrm{ei}}
$$

where $\mathrm{C}_{\mathrm{ei}}$ represents the coefficient of exergoenvironmental impact expressed as [64-66]:

$$
\mathrm{C}_{\mathrm{ei}}=\frac{1}{\eta_{\mathrm{ex}}}
$$

For any energy system there is an exergoenvironmental impact improvement that illustrates the positive effect of the energy system on the environment, which can be evaluated as [64-66]:

$$
\theta_{\mathrm{eii}}=\frac{1}{\theta_{\mathrm{ei}}}
$$

The stability factor of exergy can be obtained as [64-66]:

$$
\mathrm{f}_{\text {es }}=\frac{\dot{\mathrm{E}} \mathrm{x}_{\text {tot,des }}}{\dot{\mathrm{E} x_{\text {tot,out }}+\dot{\mathrm{E}} \mathrm{x}_{\text {tot,des }}+1}}
$$

\section{Result and Discussion}

\subsection{System Specification}

In this section, the results of the modeling that was performed in the MATLAB software are reported and discussed. One main code has been written in MATLAB. Four subroutines are written for water lithium bromide properties calculation, wind turbine energy and exergy analyses, sunrise and sunset time calculation for each day of a year, and Terminol properties calculation. Refprop software was used for R134a properties calculation. The section of the program is shown in Figure 2. 


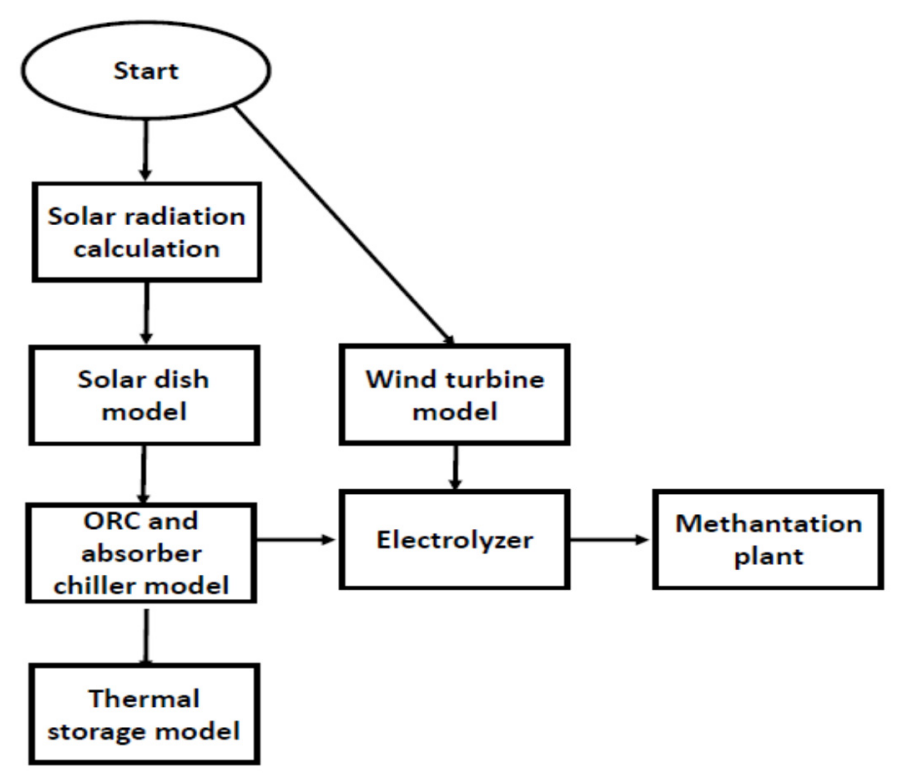

Figure 2. The subsection and methodology of the program.

The proposed system is located in the Tehran province (Iran) that has an annual average of $13 \mathrm{~h}$ of daylight per day. The city experiences relative humidity from $64 \%$ to $25 \%$ during a year. Moreover, the annual rainfall can range from $40.8 \mathrm{~mm}$ to $1.1 \mathrm{~mm}$, and the wettest month of the year can have 10 rainy days [67].

Table 6 summarizes the system's specifications, and Table 7 lists the basic parameters of the solar dish collector [51]. Table 8 includes the wind turbine specifications (model Tuge $10 \mathrm{~kW}$ [61]). The different thermodynamic properties for different points are from the system on 13:00 of 15th of July, which is shown in Table A2 in Appendix B.

Table 6. System specifications.

\begin{tabular}{ccc}
\hline Parameter & Units & Value \\
\hline$\dot{\mathrm{m}}_{1}$ & $\mathrm{~kg} \mathrm{~s}^{-1}$ & 3 \\
\hline $\mathrm{m}_{\text {storage }}$ & $\mathrm{kg}$ & 1000 \\
\hline $\mathrm{P}_{8}$ & $\mathrm{kPa}$ & 1013 \\
\hline $\mathrm{P}_{9}$ & $\mathrm{kPa}$ & 1013 \\
\hline $\mathrm{P}_{6}$ & $\mathrm{kPa}$ & 106.4 \\
\hline $\mathrm{P}_{7}$ & $\mathrm{kPa}$ & 106.4 \\
\hline$\Delta \mathrm{T}_{\text {superheat }}$ & ${ }^{\circ} \mathrm{C}$ & 20 \\
\hline$\eta_{\text {electrolyzer }}$ & - & 0.74 \\
\hline $\mathrm{T}_{5}$ & ${ }^{\circ} \mathrm{C}$ & 110 \\
\hline $\mathrm{x}_{13}$ & - & 0.41 \\
\hline $\mathrm{T}_{13}$ & ${ }^{\circ} \mathrm{C}$ & 43 \\
\hline $\mathrm{T}_{22}$ & ${ }^{\circ} \mathrm{C}$ & 80 \\
\hline $\mathrm{T}_{23}$ & ${ }^{\circ} \mathrm{C}$ & 80 \\
\hline & &
\end{tabular}


Table 7. Basic parameters of the solar dish collector [51,68-70].

\begin{tabular}{ccc}
\hline Parameter & Units & Value \\
\hline Concentration ratio & - & 28.26 \\
\hline Concentrator diameter & $\mathrm{m}$ & 3.80 \\
\hline Paraboloid rim angle & - & $45.6^{\circ}$ \\
\hline Paraboloid rim angle & $\mathrm{m}$ & 2.26 \\
\hline Collector aperture & $\mathrm{m}^{2}$ & 10.29 \\
\hline Spiral length & $\mathrm{m}$ & 9.5 \\
\hline Spiral outer mean diameter & $\mathrm{mm}$ & 12.2 \\
\hline Spiral inner maximum diameter & $\mathrm{mm}$ & 11.7 \\
\hline Spiral inner mean diameter & $\mathrm{mm}$ & 10.5 \\
\hline Spiral inner minimum diameter & $\mathrm{mm}$ & 9.3 \\
\hline Absorber emittance & - & 0.9 \\
\hline Absorber absorbance & - & 0.9 \\
\hline Mirror reflectance & - & 0.7 \\
\hline Distance between absorber and & $\mathrm{mm}$ & 2100 \\
\hline reflector base & & \\
\hline
\end{tabular}

Table 8. Wind turbine specification [61].

\begin{tabular}{ccc}
\hline Parameter & Units & Value \\
\hline$\dot{\mathrm{W}}_{\text {er,windturbine }}$ & $\mathrm{kW}$ & 10 \\
\hline $\mathrm{u}_{c}$ & $\mathrm{~m} \mathrm{~s}^{-1}$ & 3 \\
\hline $\mathrm{u}_{\mathrm{r}}$ & $\mathrm{m} \mathrm{s}^{-1}$ & 11 \\
\hline $\mathrm{u}_{\mathrm{f}}$ & $\mathrm{m} \mathrm{s}^{-1}$ & 25 \\
\hline $\mathrm{A}_{2}$ & $\mathrm{~m}^{2}$ & 82 \\
\hline Number of wind blades & - & 3 \\
\hline Tower height & $\mathrm{m}$ & 18.2 \\
\hline
\end{tabular}

\subsection{Validation of a Model}

To the best of the authors' knowledge, no similar system has been investigated before, and it is not possible to validate the results for the whole system. However, validation can be done for all of the components of the system.

For the solar dish, Equation (A5) is used, and based on the reference [55] the mean uncertainty is less than $1 \%$.

Ref. [71] is used for validation of the ORC results. The reported reference for the ORC has the same configuration with this paper, having a heat source temperature of $115^{\circ} \mathrm{C}$. The power consumption of the pump, the heat exchanging rate in the evaporator and condenser, and power production of the turbine are calculated. The physical properties of R245a are near the R134a and the conditions of both cycles are below the critical point. So, all of the main and important parameters in both cycles are checked and validated. The energy efficiency predicted by the model of the present paper is $10 \%$, which compares well with $9.7 \%$ efficiency in [71]; the mean deviation is lower than $3 \%$.

Ref [72] is used for validation of the absorption chiller results. In that reference are conducted the energy and exergy analyses of a lithium bromide absorption chiller with $90{ }^{\circ} \mathrm{C}$ generator temperature and $10 \mathrm{~kW}$ capacity. The COP calculated with the model is $79 \%$, which compares well with that of $76 \%$ reported [72], the mean deviation being close to $3.7 \%$. 
The wind turbine model is validated by comparing the evaluated monthly average output of wind turbines with the power curve given on the manufacturer webpage. Figure 3 shows the results of that comparison, with a mean deviation of $3.9 \%$.

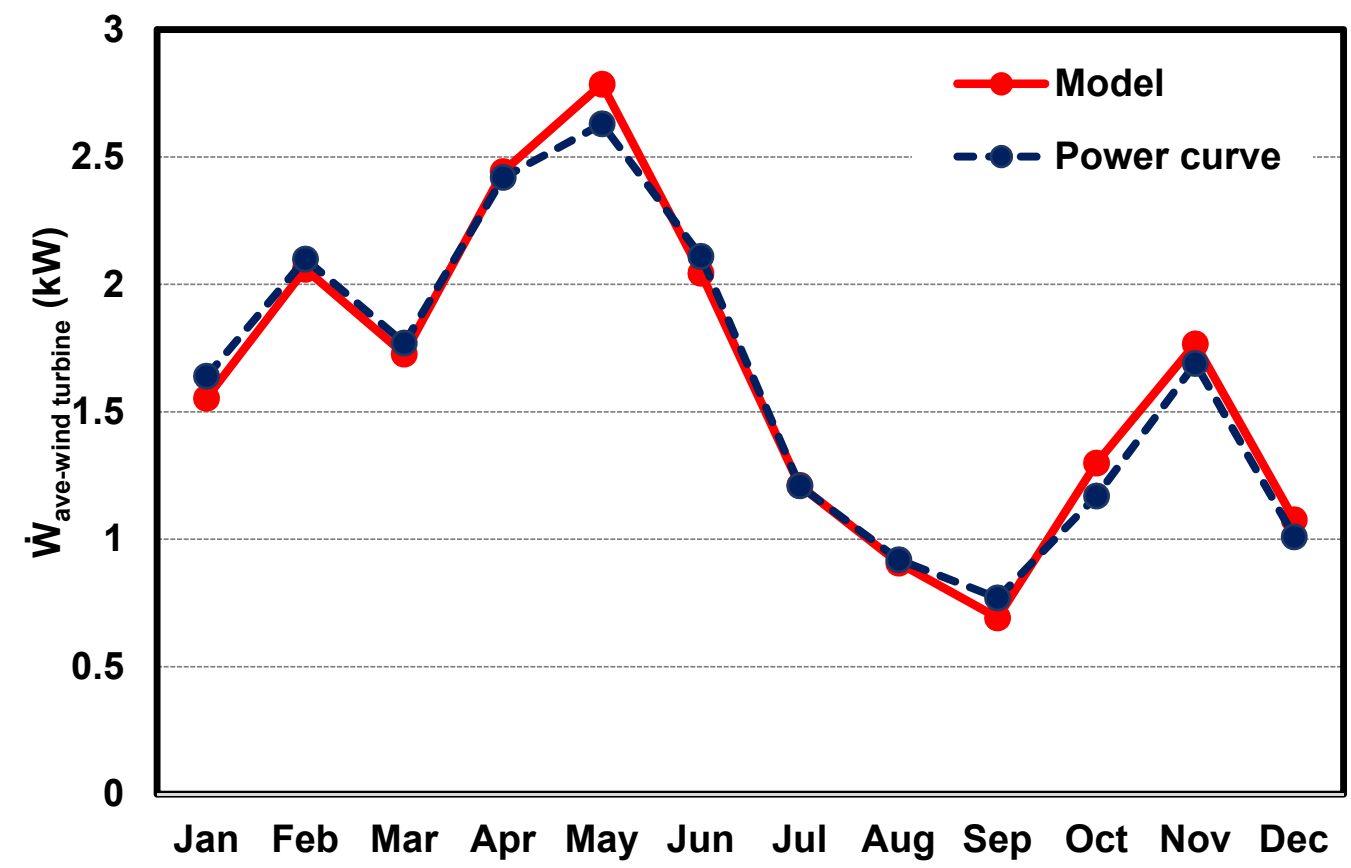

Figure 3. Results for validation of the wind turbine model.

For validation of the solar radiation, Table 1 of reference [73] is considered. In this table, the monthly average of solar radiation recorded in Iran meteorological stations from 2003 to 2010 is presented. The average error is around 3.5\%, which is acceptable in engineering calculation [74].

For modeling the PEM electrolyzer, the ref [43] is used. This paper mentioned that the error of the model is $1.5 \%$ by comparing experimental results. For validation of the methanation plant, the ref [75] is considered. The deviation of methane production by Equation (4) is $2.5 \%$. In general, by considering all of the uncertainties in various components of the system, the total error for this model is around $3.6 \%$.

\subsection{Results of Energy, Exergy Analyses}

The metrological data for Tehran are presented in Appendix B. Figure 4 shows the monthly averaged useful thermal power gain of the solar dish of the proposed system for one year. As expected, this figure follows the pattern of the monthly direct solar beam in Figure A2. It is expected a system's heat gain from solar energy changes from 1000 (in Winter) up to $2100 \mathrm{~W}$ (in Summer). According to Figure 4 , the system may experience $52 \%$ heat gain reduction during the fall season, the maximum heat gain occurs in June and July, while the minimum heat gain occurs in December. $\mathrm{s}^{-1}$

As can be seen in Figure 5, the averaged ORC electricity production for each month of a year follows a trend similar to that of the useful heat gain from the solar dish, as the ORC energy exergy source is the solar dish heat gain. The electricity production changes from $10 \mathrm{~W}$ up to $170 \mathrm{~W}$ during a year, June and December having the maximum and minimum electricity production, respectively. 


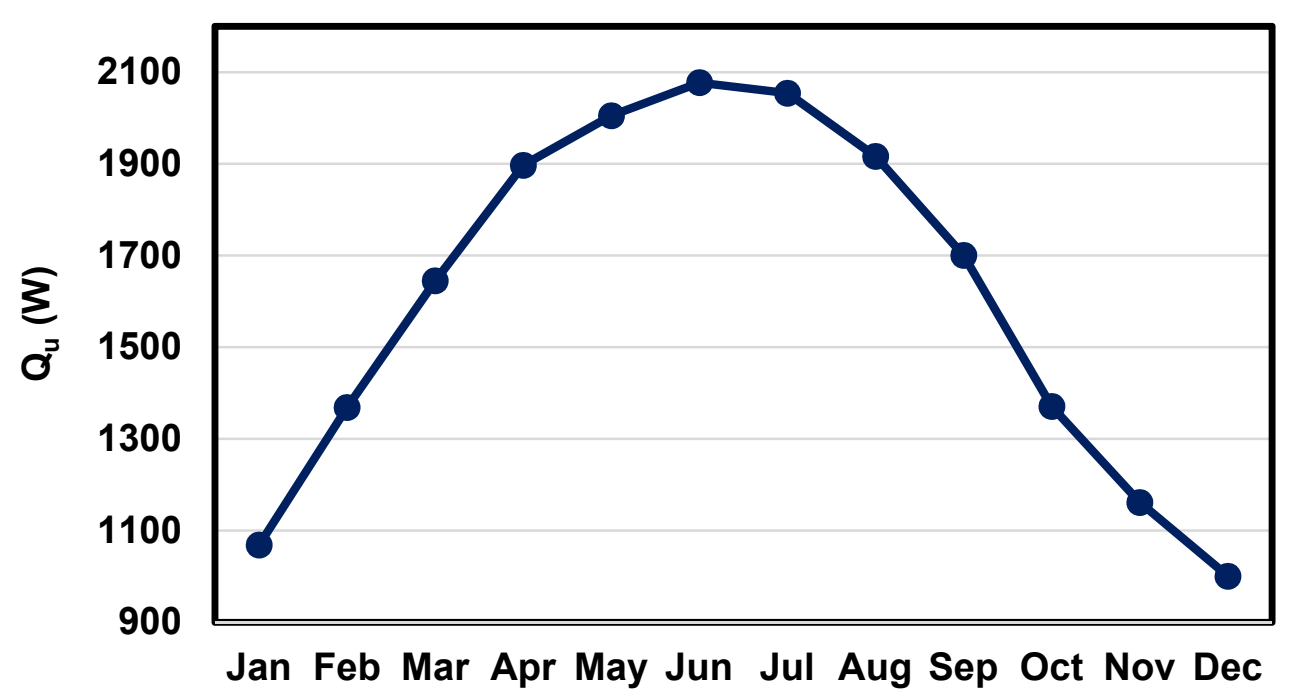

Figure 4. Monthly averaged useful heat gain from a solar dish during a year (Location: Tehran).

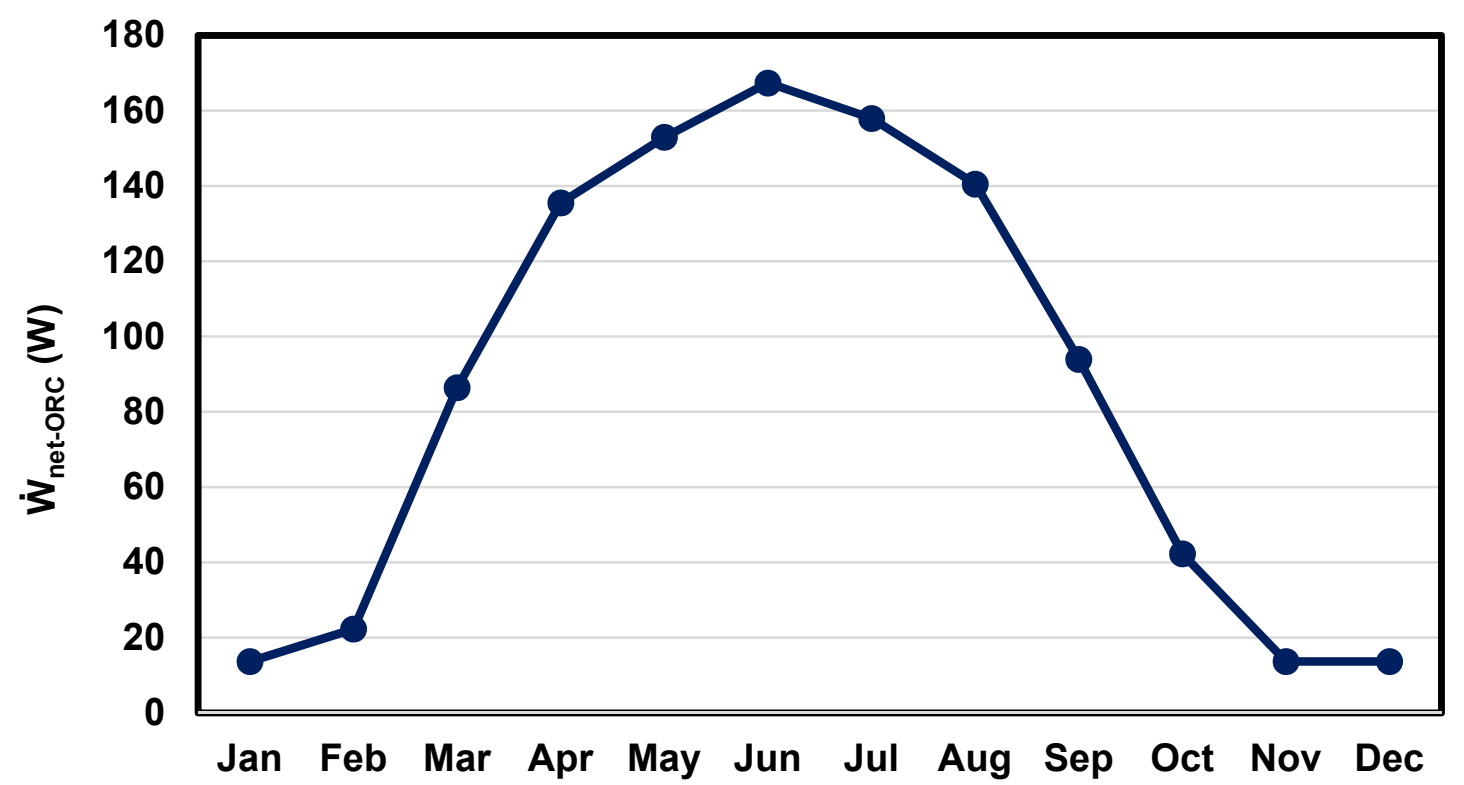

Figure 5. Monthly averaged Organic Rankine Cycle (ORC) electricity production during a year.

Fluctuations on the monthly averaged electricity production by the wind turbines, during a year, are presented in Figure 6. As expected, fluctuations in the wind turbine power generation follow the wind speed fluctuations presented in Figure A3. The maximum and minimum electricity power production from wind occur in May and September, respectively. The electricity production by the wind turbines ranges from $600 \mathrm{~W}$ up to $2700 \mathrm{~W}$, which is considerably higher than the ORC power production.

Figure 7 presents the monthly averaged hydrogen production in the PEM electrolyzer for a year. As mentioned before, since electricity consumption of the PEM electrolyzer is provided mainly by wind turbines, the trend in Figure 7 is similar to the trend in Figure A3. It is observed from Figure 7 that the minimum hydrogen production, of about $170 \mathrm{Nm}^{3} \mathrm{month}^{-1}$, occurs in September. The maximum hydrogen production of about $580 \mathrm{Nm}^{3}$ month $^{-1}$ occurs in May. 


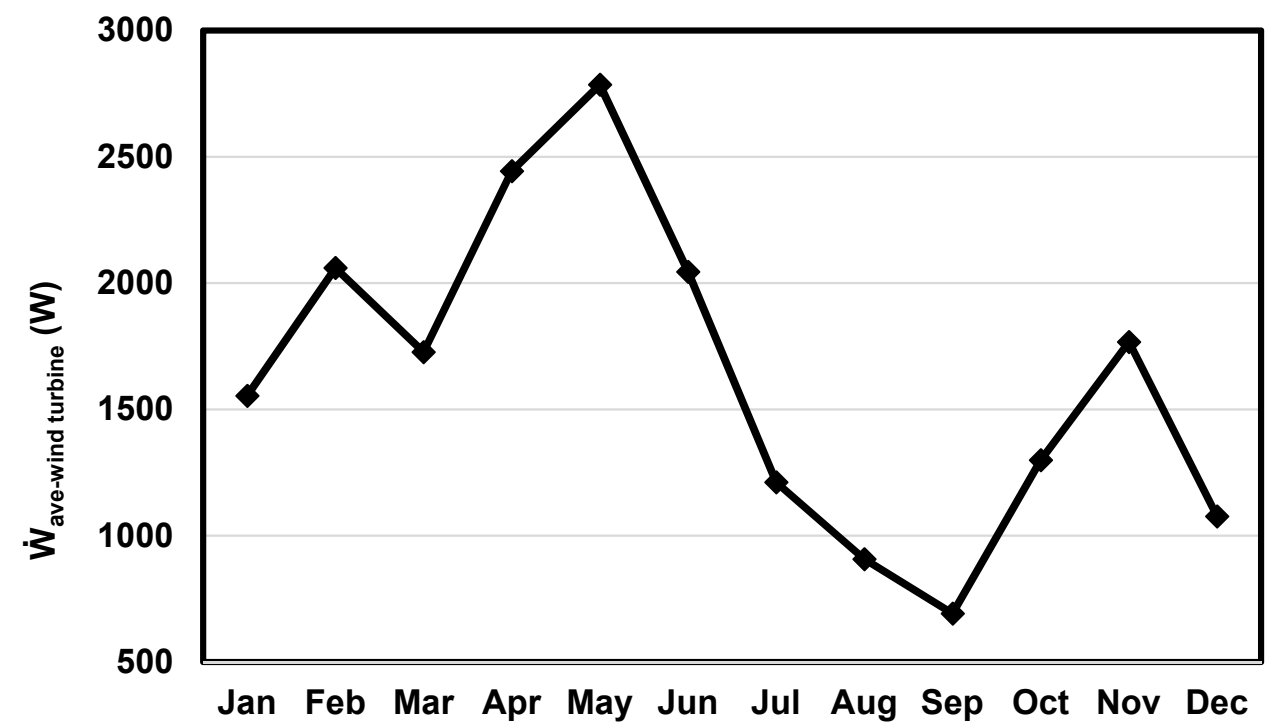

Figure 6. Monthly averaged wind turbine electricity production during a year.

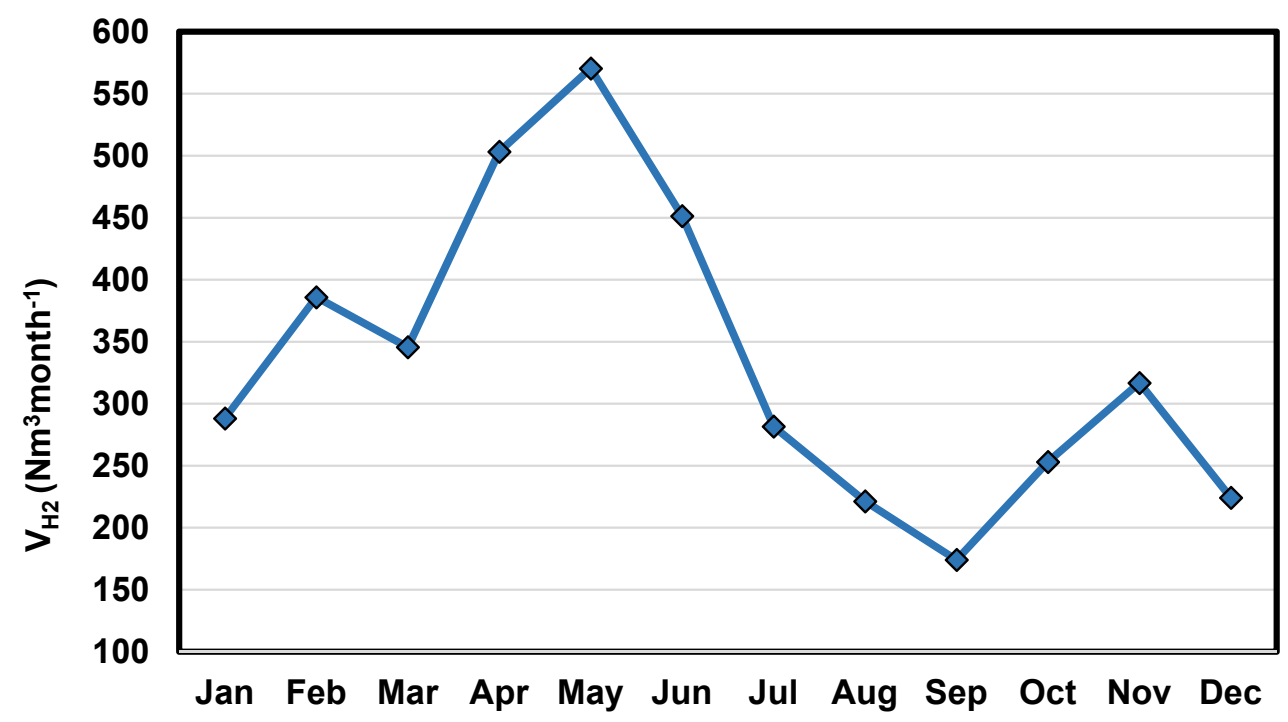

Figure 7. Monthly-average electrolyzer hydrogen production during a year.

Figure 8 presents the monthly averaged methane production of the methanation plant during a year. This figure follows a similar trend as that of the four previous figures, due to the direct link between the methane production in the methanation plant and the hydrogen production in the electrolyzer. The methane production rate changes from $42 \mathrm{Nm}^{3} \mathrm{month}^{-1}$ (in September) up to $140 \mathrm{Nm}^{3}$ month $^{-1}$ (in May) during a year.

Figure 9 presents the energy efficiency of ORC, the efficiency of the integration of ORC and absorption chiller, and the energy efficiency of the whole proposed system. As can be seen, the energy efficiency of the ORC system, ranging from $0.8 \%$ (in February) up to 3.9\% (in June), is smaller when compared with the other two energy efficiencies. The addition of the absorption chiller unit to the system leads to an increase in its energy performance, adding cooling production to the system using energy recovery from the thermal storage tank. After this integration, the efficiency range of the ORC + absorption chiller combination upgrades from $4.6 \%$ (in November and December) up to $12.2 \%$ (in February). It must be mentioned that in months with lower ORC energy efficiency, integration of the ORC with absorption chiller can have four or five times increase on the efficiency of the ORC + absorption chiller combination. However, in months with the higher ORC energy efficiency, the integration brings two or three times an increase in the efficiency of the ORC + absorption chiller 
combination. The third trend in Figure 9 refers to the energy efficiency of the whole system. As it can be observed, the energy efficiency of the whole system tends to follow a similar trend to that of the wind speed fluctuations, evidencing the major role of the wind turbines on the energy efficiency of the whole system and only a minor role of the solar radiation. The energy efficiency of the whole system changes from $9.1 \%$ (in September) up to $24.7 \%$ (in May).

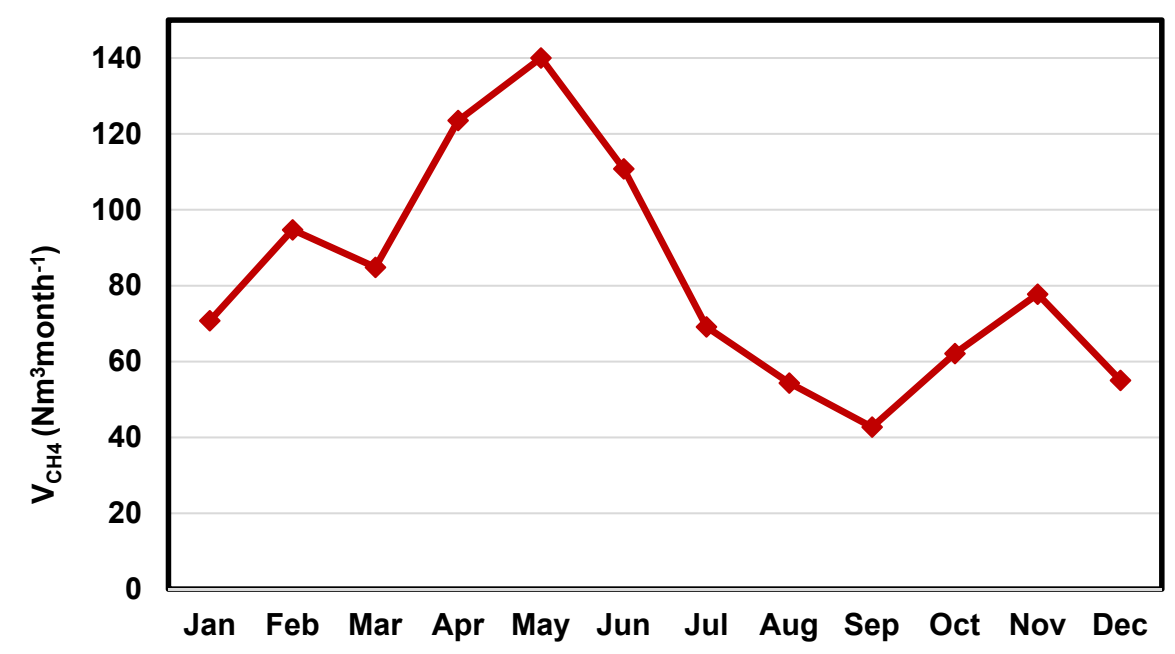

Figure 8. Monthly-average methane production of methanation plant during a year.

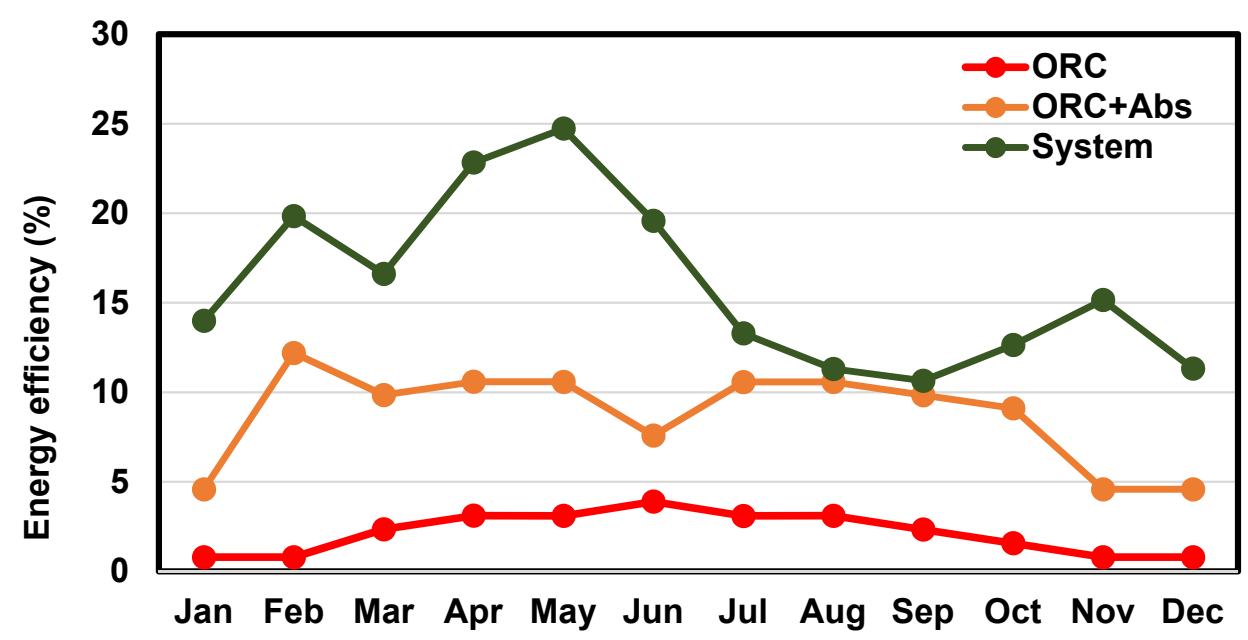

Figure 9. Monthly averaged energy efficiency of the system during a year.

Figure 10 presents the exergy efficiency of ORC, the exergy efficiency of the ORC + absorption chiller combination, and the exergy efficiency of the whole proposed system. It is seen that adding absorption chiller and wind turbines increases the exergy efficiency, even with some differences. The exergy efficiency of the ORC changes from $0.8 \%$ (in February) to $4.2 \%$ (in June). A combination of ORC with an absorption chiller increases the exergy efficiency four times in February, and the slightest increase happens in June. It is to be noted that this ORC + absorption chiller combination leads to an exergy efficiency increase that is not so notorious as the increase in energy efficiency (Figure 9). On the other hand, the exergy efficiency of the whole system is significantly enhanced because of the dominance of the products of the whole system, over the inputs when wind turbine, PEM electrolyzer, and the methanation plant are added. The exergy efficiency of the whole system changes from $8 \%$ (in September) up to 23\% (in May). Similar to what happens with the previous figures, the exergy efficiency behavior tends to follow the wind speed trend, also in this case evidencing the strong dependence of the system on the wind energy and exergy. 


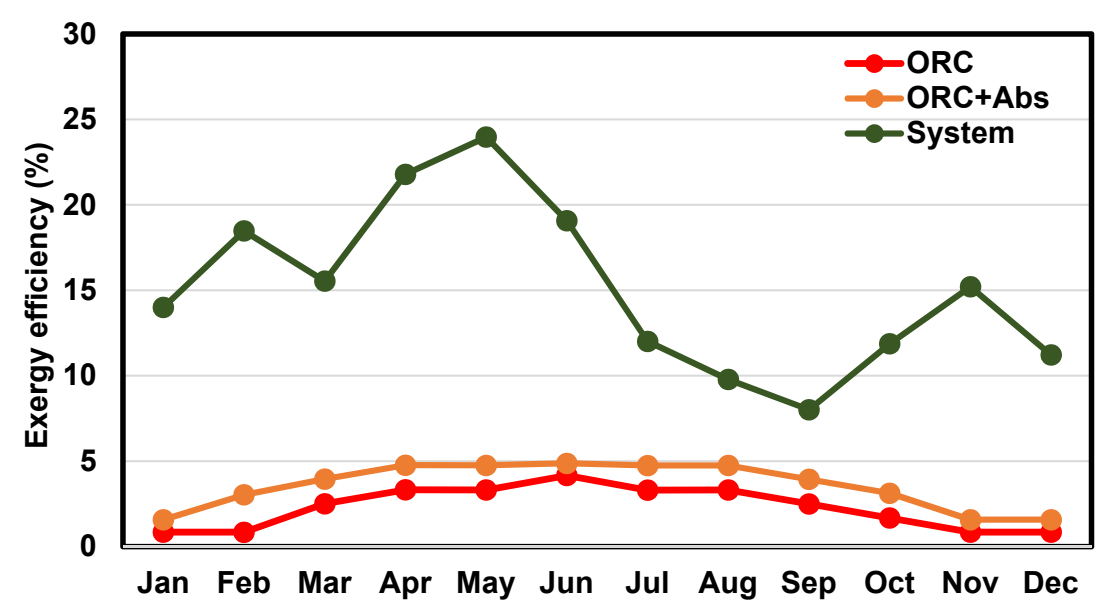

Figure 10. Monthly averaged exergy efficiency of the system during a year.

\subsection{Results of Exergoenvironment Analysis}

Table 9 shows the exergoenvironment impact factor $\left(f_{e i}\right)$, effectiveness factor of environmental damage $\left(\theta_{\mathrm{ei}}\right)$, and the stability factor of the exergy $\left(\mathrm{f}_{\mathrm{es}}\right)$.

Table 9. The fei, $\theta_{\mathrm{ei}}$, and $\mathrm{f}_{\mathrm{es}}$ for ORC, ORC + absorption chiller combination and the whole proposed system.

\begin{tabular}{cccc}
\hline & fei & Өei & fes \\
\hline ORC & 0.045 & 1.978 & 0.758 \\
\hline ORC + Abs & 0.220 & 6.188 & 0.908 \\
\hline System & 0.680 & 4.504 & 0.762 \\
\hline
\end{tabular}

This shows ORC, ORC + absorption chiller combination, and the whole proposed system. According to Equation (15), the exergoenvironment impact factor is directly affected by exergy destruction rate and has an inverse relation with input exergy to the system, which implies the fact that the lower this factor, the more acceptable the system. As it can be seen, adding absorption chiller and wind turbine both harm this exergoenvironment impact factor. The factor is less than 0.1 for ORC, which makes it the best system over the other two; integration of ORC and absorption chiller increases this factor to 0.2 , which for the whole system this factor reaches the value of 0.7 . Therefore, from the exergoenvironment impact factor, this integration is not desirable.

Similar to the exergoenvironment impact factor, the less effective factor of environmental damage, the more favorable the system. According to Equation (16), the difference in the effectiveness factor of environmental damage is that this factor is a function of exergy efficiency too, which has an inverse relation with it. This inverse relation can justify the positive impact of adding a wind turbine to the system due to its significant positive impact on the exergy efficiency of the system. Therefore, the ORC remains the best system over two, with a value of 2 of the effectiveness factor of environmental damage, and the next one is the whole system, which has a value of about 4 for this factor, and the worst case is the integration of ORC and absorption chiller with 6 for this factor.

Similarly, to the effectiveness factors of environmental damage, the case with a lower stability factor of exergy would be favorable. According to Equation (19), this factor is a function of exergy product and exergy destruction of a system. As it can be seen in Table 9, this factor is about 0.75 for ORC and the whole system, while it is about 0.9 for the unfavorable ORC + absorption chiller combination. Therefore, the proposed system has a desirable stability factor of the exergy. 


\subsection{Results of Economic Analysis}

The results of the economic analysis are listed in Table 10. As can be seen, the SPP and PP indices for the proposed system are 15.75 and 21.6 years, respectively. Total investment cost of the system and yearly income cash flow denoted respectively as $C_{0}$ and CF, are $69,665.4$ and 4423.18 US\$. The total investment gains during the lifetime of the project, presented as NPV, is calculated as being 5716.1 US\$, and the IRR of the proposed system is $4 \%$.

Table 10. Economic evaluation results.

\begin{tabular}{ccc}
\hline Parameter & Unit & Value \\
\hline SPP & years & 15.75 \\
\hline PP & years & 21.6 \\
\hline IRR & $\%$ & 3.9 \\
\hline NPV & US\$ & 5716.1 \\
\hline C $_{0}$ & US\$ & $69,665.4$ \\
\hline CF & US\$ & 4423.2 \\
\hline
\end{tabular}

\section{Conclusions}

This article presents a hybrid system based on solar and wind energy for residential applications. The system can produce electricity, heating, cooling, and syngas from captured $\mathrm{CO}_{2}$. Energy, exergy, economic, and exergoenvironmental analyses (4E) are performed for the system to evaluate the performance from different viewpoints and the feasibility of the system. This proposed system can be used in regions with windy and high solar radiation condition to recover the renewable energy resources to produce electricity, syngas, heating, and cooling respectively.

The result of the system assessment can be summarized as follows:

- The maximum and minimum electricity production from the ORC system is 170 and $10 \mathrm{~W}$ in June and December, respectively.

- Electricity production from wind turbines ranges from $600 \mathrm{~W}$ in September up to 2700 in May.

- In the methanation plant, syngas production is maximum in May about $140 \mathrm{Nm}^{3} \mathrm{month}^{-1}$, which in September experiences its lowest amount about $42 \mathrm{Nm}^{3} \mathrm{month}^{-1}$. The energy efficiency of the system changes from $24.7 \%$ (in May) to $9.1 \%$ (in September) during a year. Furthermore, annually, the exergy efficiency of the whole system ranges from $8 \%$ (in September) up to $23 \%$ (in May).

- For those three cases, stability factors of exergy are calculated and compared. This factor for ORC, ORC + absorption chiller combination and the whole system are respectively $0.75,0.9,0.75$. Therefore, ORC and the whole system are the best cases, and ORC + absorption chiller integration is not favorable.

- The simple payback period and the payback period of the system are respectively 15.6 and 21.4 years. The total investment cost of the system and yearly income cash flow are 69,129.54 and 4423.18 US\$. The net present value is 5818.13 US\$, and the internal rate of return is $4 \%$.

Author Contributions: S.E.; Conceptualization and Methodology. S.B.; Software and Visualization. M.A.; Conceptualization and Project administration, M.A.E.; Conceptualization, Methodology, Software, Visualization, and Writing-Original Draft. A.A.; Methodology, Software, Visualization, and Writing-Original Draft, A.A.R.; Project administration and Writing—review and Editing, B.D.; Writing-review and editing, V.A.F.C.; Writing - review and editing. A.D.; Software, Writing-review and editing and Supervision. All authors have read and agreed to the published version of the manuscript.

Funding: This research received no external funding.

Conflicts of Interest: The authors declare no conflict of interest. 


\section{Nomenclature}

\begin{tabular}{|c|c|}
\hline & Variables \\
\hline $\mathbf{A}_{\mathbf{a}}$ & Aperture of the solar dish $\left(\mathrm{m}^{2}\right)$ \\
\hline CF & Cost function (\$) \\
\hline $\mathrm{C}$ & Parameter of wind turbine \\
\hline $\mathrm{C}_{0}$ & Total investment cost (US\$) \\
\hline $\mathrm{C}_{\mathrm{ei}}$ & Coefficient of exergoenvironment impact \\
\hline CF & Income cash flow (US\$) \\
\hline $\mathrm{Cp}$ & Constant pressure specific heat $\left(\mathrm{J} \mathrm{kg}^{-1} \mathrm{~K}^{-1}\right)$ \\
\hline COP & Coefficient of performance \\
\hline E & Specific parameter obtained from Equation (2) \\
\hline ex & Total specific exergy $\left(\mathrm{J} \mathrm{kg}^{-1}\right)$ \\
\hline$e_{\text {chi }}$ & Specific chemical exergy of component I $\left(\mathrm{J} \mathrm{kg}^{-1}\right)$ \\
\hline$\dot{\mathrm{E}}_{\mathbf{D}}$ & Exergy destruction rate $(\mathrm{W})$ \\
\hline $\mathbf{F}$ & Faraday's constant $\left(96,495 \mathrm{C}^{\prime}\right.$ mole $\left.^{-1}\right)$ \\
\hline $\mathrm{f}_{\mathrm{ei}}$ & Exergoenvironment impact factor \\
\hline$f_{e s}$ & Stability factor of exergy \\
\hline Gb & Direct normal irradiance $\left(\mathrm{W} \mathrm{m}^{-2}\right)$ \\
\hline HTF & Heat transfer fluid \\
\hline h & Specific Enthalpy $\left(\mathrm{J} \mathrm{kg}^{-1}\right)$ \\
\hline IRR & Internal Rate of Return \\
\hline $\mathbf{K}$ & Parameter of wind turbine \\
\hline $\mathbf{K}$ & Investment cost of a component (US\$) \\
\hline k & Specific cost of the products (US\$ unit ${ }^{-1}$ ) \\
\hline KK & Number of wind turbines \\
\hline Lst & Standard meridian for the local time zone (degrees) \\
\hline Lloc & Longitude of the location (degrees) \\
\hline HHV & Higher heating value $\left(\mathrm{J} \mathrm{kg}^{-1}\right)$ \\
\hline$\dot{\mathbf{m}}$ & Mass flow rate $\left(\mathrm{kg} \mathrm{s}^{-1}\right)$ \\
\hline$\dot{\mathrm{m}}_{\mathrm{H} 2}$ & Hydrogen production mass flow rate in alkaline electrolyzer $\left(\mathrm{kg} \mathrm{s}^{-1}\right)$ \\
\hline NPV & Net Present Value (US\$) \\
\hline $\mathbf{N}$ & Project lifetime (equal to 25 years) \\
\hline PP & Payback period (years) \\
\hline$\dot{\mathbf{Q}}$ & Heat transfer rate $(\mathrm{W})$ \\
\hline $\mathbf{R}$ & Universal gas constant: $\mathrm{R}=8.314\left(\mathrm{~J} \mathrm{~mole}^{-1} \mathrm{~K}^{-1}\right)$ \\
\hline $\mathbf{r}$ & Discount factor (equal to 3\%) \\
\hline$S$ & Specific entropy $\left(\mathrm{J} \mathrm{kg}^{-1} \mathrm{~K}^{-1}\right)$ \\
\hline SPP & Simple Payback Period (years) \\
\hline $\mathbf{T}$ & Temperature (K) \\
\hline $\mathbf{T}_{\mathrm{s}}$ & Solar time (s) \\
\hline $\mathrm{T}_{\mathrm{ls}}$ & Local solar time (s) \\
\hline $\mathbf{u}$ & Wind velocity $\left(\mathrm{m} \mathrm{s}^{-1}\right)$ \\
\hline$\overline{\mathbf{u}}$ & Average wind speed $\left(\mathrm{m} \mathrm{s}^{-1}\right)$ \\
\hline $\mathbf{u}_{\mathrm{c}}$ & Cut-in speed $\left(\mathrm{m} \mathrm{s}^{-1}\right)$ \\
\hline $\mathbf{u}_{\mathbf{r}}$ & Rated speed $\left(\mathrm{m} \mathrm{s}^{-1}\right)$ \\
\hline $\mathbf{u}_{\mathbf{f}}$ & Furling speed $\left(\mathrm{m} \mathrm{s}^{-1}\right)$ \\
\hline $\mathbf{V}$ & Voltage (V) \\
\hline$\dot{\mathbf{W}}$ & Work transfer rate $(\mathrm{W})$ \\
\hline $\mathbf{x}$ & Mass fraction \\
\hline $\mathbf{Y}$ & Yearly energy parameter \\
\hline
\end{tabular}




\section{Greek Symbols}

$\delta \quad$ Deflection angle (Degree)

$\sigma \quad$ Standard deviation

$\boldsymbol{\theta}_{\boldsymbol{z}} \quad$ Zenith angle (Degree)

$\theta_{\text {ei }} \quad$ Effectiveness factor of environmental damage

$\theta_{\text {eii }} \quad$ Exergoenvironmental impact improvement Factor

$\beta \quad$ Constant parameter

$\varphi \quad$ Latitude angle (Degree)

$\eta \quad$ Efficiency

$\eta_{\mathbf{V}} \quad$ Efficiency of the electrolyzer

$\theta_{\mathrm{Z}} \quad$ Zenith angle (Degree)

$\omega \quad$ Angle of sunset hour (Degree)

r Gamma function

\section{Subscripts}

0 Reference state condition (1 atm, $288 \mathrm{~K}$ )

1, 2, . , 23 Points in Figure 1

amb Ambient

ave Average

C Cooling load

chi Chemical energy for component $\mathrm{i}$

$\mathrm{CH} 4 \quad$ Methane $\left(\mathrm{CH}_{4}\right)$

$\mathrm{CO}_{2} \quad$ Carbone dioxide $\left(\mathrm{Co}_{2}\right)$

Con Condenser

elec Eletrolyzer

Eva Evaporator

Gen Generator

$\mathbf{H} \quad$ Heating load

P Pump

S Solar

SOFC Solid oxide fuel cell

u Useful

\section{Abbreviations}

$\begin{array}{ll}\text { Jan } & \text { January } \\ \text { Feb } & \text { February } \\ \text { Mar } & \text { March } \\ \text { Apr } & \text { April } \\ \text { May } & \text { May } \\ \text { Jun } & \text { June } \\ \text { Jul } & \text { July } \\ \text { Aug } & \text { August } \\ \text { Sep } & \text { September } \\ \text { Oct } & \text { October } \\ \text { Nov } & \text { November } \\ \text { Dec } & \text { December }\end{array}$

\section{Appendix A}

Appendix A.1. Solar Radiation Collection

The sunny time can be expressed as follows [76]:

$$
\mathrm{T}_{\mathrm{ls}}=\mathrm{T}_{\mathrm{s}}+4\left(\mathrm{~L}_{\mathrm{loc}}-\mathrm{L}_{\mathrm{st}}\right)+\mathrm{E}
$$


where $\mathrm{T}_{\mathrm{ls}}$ and $\mathrm{T}_{\mathrm{S}}$ denote local and solar times, respectively, $\mathrm{L}_{\mathrm{loc}}$ is the longitude, and local standard time meridian is denoted as $\mathrm{L}_{\mathrm{st}}$, and $\mathrm{E}$ is obtained as [76]:

$$
\mathrm{E}=229.2(0.000075+0.001868 \cos \beta-0.032077 \sin \beta-0.014615 \cos 2 \beta-0.04089 \sin 2 \beta)
$$

$\beta=\frac{360(n-1)}{365}$, and for January first $\mathrm{n}$ is equal to 1 . The angle of sunset hour is evaluated as [76]:

$$
\omega=\arccos (-\tan \varphi \tan \delta)
$$

where $\varphi$ is the latitude angle. $\delta$ is the deflection angle, evaluated as [76]:

$$
\delta=23.45 \sin \left(\frac{360(284+\mathrm{n})}{365}\right)
$$

The thermal efficiency of the solar dish was obtained as [55]:

$$
\eta_{\text {th }}=0.68199-0.19456 \frac{T_{\text {in }}-T_{a m}}{G_{b}}-0.00056 \frac{\left(T_{i n}-T_{a m}\right)^{2}}{G_{b}}
$$

where $G_{b}$ is the solar direct beam irradiation, and $T_{i n}$ and $T_{a m}$ are the inlets and ambient temperatures of the solar dish. This expression was obtained using a detailed numerical model, validated with experimental studies. The regression model used for that purpose has a correlation factor $\mathrm{R}^{2}=0.9997$ [55].

The useful heat obtained from the dish collector is evaluated as [55]:

$$
\begin{aligned}
& \dot{\mathrm{Q}}_{\mathrm{u}}=\eta_{\mathrm{th}} \dot{\mathrm{Q}}_{\mathrm{S}} \\
& \dot{\mathrm{Q}}_{\mathrm{S}}=\mathrm{A}_{\mathrm{a}} \mathrm{G}_{\mathrm{b}}
\end{aligned}
$$

The energy balance for the storage tank is calculated as follows:

$$
\dot{\mathrm{Q}}_{\mathrm{u}}=\mathrm{Mc}_{\mathrm{p}} \frac{\partial \mathrm{T}}{\partial \mathrm{t}}+\dot{\mathrm{m}}_{3} \mathrm{~h}_{3}-\dot{\mathrm{m}}_{4} \mathrm{~h}_{4}-\dot{\mathrm{m}}_{1} \mathrm{~h}_{1}-\dot{\mathrm{Q}}_{\text {loss }}
$$

In which, $\mathrm{M}$ is the mass in the storage tank. $\dot{\mathrm{Q}}_{\text {loss }}$ is assumed $5 \%$ of $\dot{\mathrm{Q}}_{\mathrm{u}}$.

where $A_{a}$ is the aperture surface area of the solar dish, and $G_{b}$ can be obtained as [76]:

$$
\mathrm{Gb}=\mathrm{A} \cos \theta_{\mathrm{Z}} \exp \left(\frac{-\mathrm{B}}{\cos \theta_{\mathrm{Z}}}\right)
$$

where $\theta_{Z}$ denotes zenith angle, and $A$ and $B$ are constants [76].

\section{Appendix A.2. Wind Energy Harvesting}

The average electric power that can be produced in wind turbines is expressed as [40]:

$$
\dot{\mathrm{W}}_{\text {wind.ave }}=\dot{\mathrm{W}}_{\text {wind.er }}\left[\frac{\exp \left(-\left(\frac{\mathrm{u}_{\mathrm{c}}}{\mathrm{C}}\right)\right)^{\mathrm{K}}-\exp \left(-\left(\frac{\mathrm{u}_{\mathrm{r}}}{\mathrm{C}}\right)\right)^{\mathrm{K}}}{\left(\frac{\mathrm{u}_{\mathrm{r}}}{\mathrm{C}}\right)^{\mathrm{K}}-\left(\frac{\mathrm{u}_{\mathrm{c}}}{\mathrm{C}}\right)^{\mathrm{K}}}-\exp \left(-\left(\frac{\mathrm{u}_{\mathrm{f}}}{\mathrm{C}}\right)\right)^{\mathrm{K}}\right]
$$

where $\mathrm{u}_{\mathrm{c}}, \mathrm{u}_{\mathrm{r}}$, and $\mathrm{u}_{\mathrm{f}}$ denote cut-in and furling speeds, and $\mathrm{C}$ and $\mathrm{K}$ can be obtained as $[77,78]$ :

$$
\begin{aligned}
& \mathrm{C}=\frac{\overline{\mathrm{u}}}{\Gamma\left(1+\frac{1}{\mathrm{k}}\right)} \\
& \mathrm{K}=\left(\frac{\sigma}{\overline{\mathrm{u}}}\right)^{-1.086}
\end{aligned}
$$

In these equations, $\overline{\mathrm{u}}$ is the average wind speed, $\Gamma$ is the Gamma function, and $\sigma$ denotes the wind speed standard deviation. 


\section{Appendix B}

Figure A1 presents the monthly averaged minimum, maximum, and average ambient temperatures of each month for Tehran for a year. As it can be seen on the $\mathrm{T}_{\max }$ curve, August and February have the maximum and minimum ambient temperature, respectively, with $40{ }^{\circ} \mathrm{C}$ ambient temperature amplitude. However, according to the $\mathrm{T}_{\text {mean }}$ curve, July has the maximum ambient temperature, and the temperature of the city during a year generally ranges from 15 up to $35^{\circ} \mathrm{C}$.

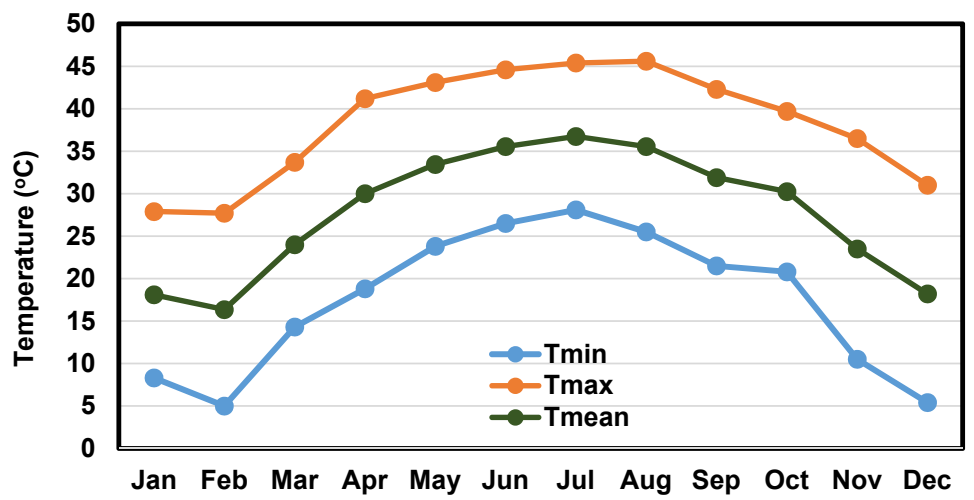

Figure A1. Monthly averaged ambient temperature of Tehran during a year.

Figure A2 presents the monthly averaged direct beam solar radiation for Tehran. April, May, Jun, July, and August have significant potential for solar radiation use (spring and summer seasons). Fall and winter seasons have solar radiation below $200 \mathrm{~W} / \mathrm{m}^{2}$ in Tehran. The direct beam radiation presents a $100 \%$ increase in June when compared with the lowest solar radiation in December.

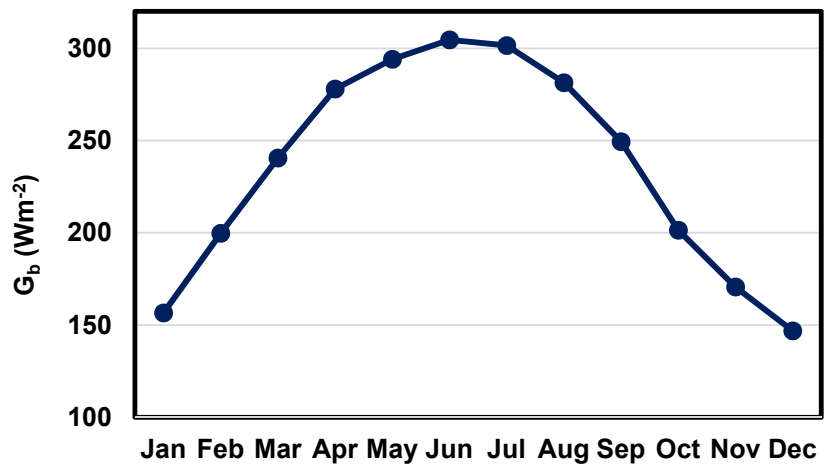

Figure A2. Monthly- average solar radiation of Tehran during a year.

Table A1 shows the number of air flows in specific wind velocity ranges during various months of a year.

Figure A3 shows the monthly averaged wind velocity in each month of a year. Five different wind speed ranges are considered, and the highest average wind velocity during a year belongs to the first range for which wind speed changes from 1 to $3 \mathrm{~m} / \mathrm{s}$. Spring months reveal the highest average wind velocity in different wind speed ranges. As it can be observed in Figure A3, winter and spring seasons have the highest average wind speed, ranging from 4 to $5.5 \mathrm{~m} / \mathrm{s}$, and the lowest average wind speed occurs in summer, though December has the lowest wind speed.

Table A1. Wind velocity value at a variety of wind speed ranges for Tehran during a year [67].

\begin{tabular}{ccccccccccccc}
\hline Wind Speed $\left(\mathbf{m ~ s}^{-1}\right)$ & Jan & Feb & Mar & Apr & May & Jun & Jul & Aug & Sep & Oct & Nov & Dec \\
\hline $\mathbf{1} \leq \boldsymbol{u}_{\mathbf{1}}<\mathbf{3}$ & 59 & 62 & 82 & 79 & 71 & 76 & 98 & 106 & 119 & 96 & 64 & 60 \\
\hline $\mathbf{4} \leq \boldsymbol{u}_{\mathbf{1}}<\mathbf{6}$ & 25 & 36 & 65 & 61 & 53 & 67 & 73 & 51 & 43 & 37 & 31 & 8 \\
\hline $\mathbf{7} \leq \boldsymbol{u}_{\mathbf{1}}<\mathbf{1 0}$ & 15 & 22 & 20 & 32 & 27 & 27 & 7 & 5 & 6 & 10 & 14 & 2 \\
\hline $\mathbf{1 1} \leq \boldsymbol{u}_{\mathbf{1}}<\mathbf{1 6}$ & 0 & 2 & 2 & 7 & 12 & 3 & 2 & 1 & 0 & 2 & 2 & 2 \\
\hline $\boldsymbol{u}_{\mathbf{1}}>\mathbf{1 6}$ & 0 & 0 & 0 & 0 & 0 & 0 & 0 & 0 & 0 & 0 & 0 & 0 \\
\hline
\end{tabular}




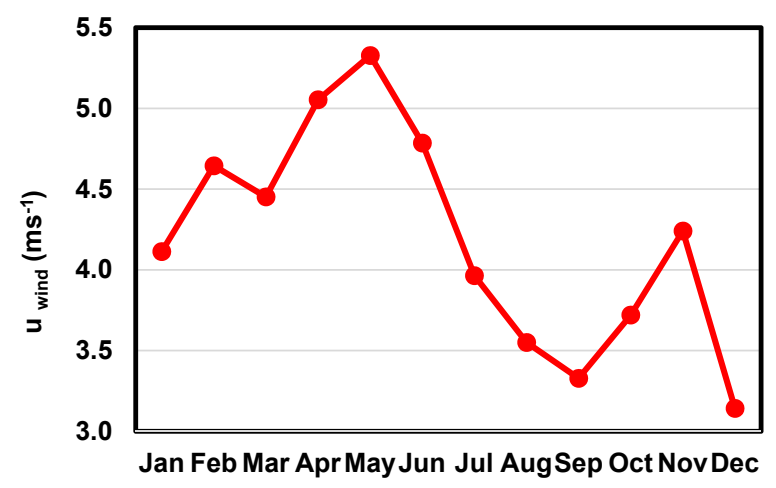

Figure A3. Monthly- average wind speed fluctuations of Tehran during a year.

The different thermodynamic properties for different points from the system on 13:00 of 15th of July are shown in Table A2 in Appendix B.

Table A2. The different thermodynamic properties for different points are from the system on 13:00 of 15 th of July.

\begin{tabular}{|c|c|c|c|c|}
\hline No. & Temperature (K) & Pressure (kPa) & Mass Flow Rate (kg s$\left.{ }^{-1}\right)$ & Enthalpy $\left(\mathrm{kJ} \mathrm{kg}^{-1}\right)$ \\
\hline 1 & 331.250 & 101.300 & 1.00000 & 794.114 \\
\hline 2 & 332.750 & 202.600 & 1.00000 & 799.186 \\
\hline 3 & 345.150 & 196.522 & 1.00000 & 841.966 \\
\hline 4 & 343.250 & 101.300 & 1.00000 & 835.305 \\
\hline 5 & 342.710 & 202.600 & 1.00000 & 833.423 \\
\hline 6 & 251.100 & 121.600 & 0.03000 & 385.305 \\
\hline 7 & 250.440 & 117.900 & 0.03000 & 170.139 \\
\hline 8 & 252.460 & 1013.000 & 0.03000 & 173.024 \\
\hline 9 & 330.890 & 982.600 & 0.03000 & 440.513 \\
\hline 10 & 328.150 & 8.128 & 0.00970 & 122.159 \\
\hline 11 & 328.150 & 3.236 & 0.00747 & 124.229 \\
\hline 12 & 316.500 & 1.681 & 0.00747 & 99.302 \\
\hline 13 & 316.500 & 4.403 & 0.00970 & 93.164 \\
\hline 14 & 328.150 & 8.128 & 0.00227 & 2576.300 \\
\hline 15 & 314.700 & 8.128 & 0.00227 & 174.095 \\
\hline 16 & 316.500 & 4.403 & 0.00227 & 174.095 \\
\hline 17 & 316.500 & 4.403 & 0.00227 & 2556.300 \\
\hline 18 & 298.300 & 101.300 & 0.00016 & 105.547 \\
\hline 19 & 298.300 & 101.300 & 0.00002 & 3931.716 \\
\hline 20 & 298.500 & 101.300 & 0.00010 & 505.969 \\
\hline 21 & 353.150 & 202.600 & 0.00004 & 910.288 \\
\hline 22 & 331.210 & 196.500 & 1.00000 & 793.980 \\
\hline 23 & 330.750 & 190.600 & 1.00000 & 792.429 \\
\hline 24 & 329.750 & 184.880 & 1.00000 & 789.064 \\
\hline 25 & 329.470 & 179.330 & 1.00000 & 788.124 \\
\hline 26 & 328.890 & 173.950 & 1.00000 & 786.178 \\
\hline 27 & 298.500 & 101.300 & 0.00015 & 271.148 \\
\hline 28 & 353.150 & 202.160 & 0.00008 & 105.547 \\
\hline
\end{tabular}




\section{References}

1. Alizadeh, S.; Ghazanfari, A.; Ehyaei, M.; Ahmadi, A.; Jamali, D.; Nedaei, N.; Davarpanah, A. Investigation the integration of heliostat solar receiver to gas and combined cycles by energy, exergy, and economic point of views. Appl. Sci. 2020, 10, 5307. [CrossRef]

2. Hu, X.; Xie, J.; Cai, W.; Wang, R.; Davarpanah, A. Thermodynamic effects of cycling carbon dioxide injectivity in shale reservoirs. J. Pet. Sci. Eng. 2020, 195, 107717. [CrossRef]

3. Jin, Y.; Davarpanah, A. Using Photo-Fenton and Floatation Techniques for the Sustainable Management of Flow-Back Produced Water Reuse in Shale Reservoirs Exploration. Water Air Soil Pollut. 2020, $231,441$. [CrossRef]

4. Valizadeh, K.; Farahbakhsh, S.; Bateni, A.; Zargarian, A.; Davarpanah, A.; Alizadeh, A.; Zarei, M. A parametric study to simulate the non-Newtonian turbulent flow in spiral tubes. Energy Sci. Eng. 2020, 8, 134-149. [CrossRef]

5. Ehyaei, M.A.; Bahadori, M.N. Internalizing the Social Cost of Noise Pollution in the Cost Analysis of Electricity Generated by Wind Turbines. Wind Eng. 2006, 30, 521-529. [CrossRef]

6. Zarei, M.; Davarpanah, A.; Mokhtarian, N.; Farahbod, F. Integrated feasibility experimental investigation of hydrodynamic, geometrical and, operational characterization of methanol conversion to formaldehyde. Energy Sources Part A Recovery Util. Environ. 2020, 42, 89-103. [CrossRef]

7. Ehyaei, M.; Ahmadi, A.; Rosen, M.A.; Davarpanah, A. Thermodynamic Optimization of a Geothermal Power Plant with a Genetic Algorithm in Two Stages. Processes 2020, 8, 1277. [CrossRef]

8. Ehyaei, M.A.; Ahmadi, A.; Assad, M.E.H.; Hachicha, A.A.; Said, Z. Energy, exergy and economic analyses for the selection of working fluid and metal oxide nanofluids in a parabolic trough collector. Sol. Energy 2019, 187, 175-184. [CrossRef]

9. Sheikhani, H.; Barzegarian, R.; Heydari, A.; Kianifar, A.; Kasaeian, A.; Gróf, G.; Mahian, O. A review of solar absorption cooling systems combined with various auxiliary energy devices. J. Therm. Anal. Calorim. 2018, 134, 2197-2212. [CrossRef]

10. Davarpanah, A. Feasible analysis of reusing flowback produced water in the operational performances of oil reservoirs. Environ. Sci. Pollut. Res. 2018, 25, 35387-35395. [CrossRef]

11. Davarpanah, A.; Mirshekari, B. Experimental Investigation and Mathematical Modeling of Gas Diffusivity by Carbon Dioxide and Methane Kinetic Adsorption. Ind. Eng. Chem. Res. 2019, 58, 12392-12400. [CrossRef]

12. Ahmadi, A.; Ehyaei, M.A.; Doustgani, A.; Assad, M.e.; Hmida, A.; Jamali, D.H.; Kumar, R.; Li, Z.X.; Razmjoo, A. Recent residential applications of low-temperature solar collector. J. Clean. Prod. 2021, 279, 123549. [CrossRef]

13. Shaygan, M.; Ehyaei, M.A.; Ahmadi, A.; Assad, M.E.H.; Silveira, J.L. Energy, exergy, advanced exergy and economic analyses of hybrid polymer electrolyte membrane (PEM) fuel cell and photovoltaic cells to produce hydrogen and electricity. J. Clean. Prod. 2019, 234, 1082-1093. [CrossRef]

14. Ehyaei, M.; Farshin, B. Optimization of photovoltaic thermal (PV/T) hybrid collectors by genetic algorithm in Iran's residential areas. Adv. Energy Res. 2017, 5, 31-55. [CrossRef]

15. Ehyaei, M.A.; Ahmadi, A.; Assad, M.E.; Rosen, M.A. Investigation of an integrated system combining an Organic Rankine Cycle and absorption chiller driven by geothermal energy: Energy, exergy, and economic analyses and optimization. J. Clean. Prod. 2020, 258, 120780. [CrossRef]

16. Ahmadi, A.; Jamali, D.; Ehyaei, M.; Assad, M.E.H. Energy, exergy, economic and exergoenvironmental analyses of gas and air bottoming cycles for production of electricity and hydrogen with gas reformer. J. Clean. Prod. 2020, 259, 120915. [CrossRef]

17. Davarpanah, A. Parametric study of polymer-nanoparticles-assisted injectivity performance for axisymmetric two-phase flow in EOR processes. Nanomaterials 2020, 10, 1818. [CrossRef]

18. Talebizadehsardari, P.; Ehyaei, M.; Ahmadi, A.; Jamali, D.; Shirmohammadi, R.; Eyvazian, A.; Ghasemi, A.; Rosen, M.A. Energy, exergy, economic, exergoeconomic, and exergoenvironmental (5E) analyses of a triple cycle with carbon capture. J. $\mathrm{CO}_{2}$ Util. 2020, 41, 101258. [CrossRef]

19. Ahmadi, A.; Assad, M.E.H.; Jamali, D.; Kumar, R.; Li, Z.; Salameh, T.; Al-Shabi, M.; Ehyaei, M. Applications of Geothermal Organic Rankine Cycle for Electricity Production. J. Clean. Prod. 2020, 274, 122950. [CrossRef]

20. Wang, X.; Zhao, L.; Wang, J.; Zhang, W.; Zhao, X.; Wu, W. Performance evaluation of a low-temperature solar Rankine cycle system utilizing R245fa. Sol. Energy 2010, 84, 353-364. [CrossRef] 
21. Wang, M.; Wang, J.; Zhao, P.; Dai, Y. Multi-objective optimization of a combined cooling, heating and power system driven by solar energy. Energy Convers. Manag. 2015, 89, 289-297. [CrossRef]

22. Wang, J.; Yan, Z.; Wang, M.; Song, Y.; Dai, Y. Parametric analysis and optimization of a building cooling heating power system driven by solar energy based on organic working fluid. Int. J. Energy Res. 2013, 37, 1465-1474. [CrossRef]

23. Calise, F.; d'Accadia, M.D.; Macaluso, A.; Piacentino, A.; Vanoli, L. Exergetic and exergoeconomic analysis of a novel hybrid solar-geothermal polygeneration system producing energy and water. Energy Convers. Manag. 2016, 115, 200-220. [CrossRef]

24. Bellos, E.; Tzivanidis, C. Multi-objective optimization of a solar driven trigeneration system. Energy 2018, 149, 47-62. [CrossRef]

25. Gogoi, T.; Saikia, S. Performance analysis of a solar heat driven Organic Rankine Cycle and Absorption Cooling System. Therm. Sci. Eng. Prog. 2019, 13, 100372. [CrossRef]

26. El-Emam, R.S.; Dincer, I. Assessment and Evolutionary Based Multi-Objective Optimization of a Novel Renewable-Based Polygeneration Energy System. J. Energy Resour. Technol. 2017, 139, 012003. [CrossRef]

27. Khalid, F.; Dincer, I.; Rosen, M.A. Thermoeconomic analysis of a solar-biomass integrated multigeneration system for a community. Appl. Therm. Eng. 2017, 120, 645-653. [CrossRef]

28. El-Emam, R.S.; Dincer, I. Development and assessment of a novel solar heliostat-based multigeneration system. Int. J. Hydrog. Energy 2018, 43, 2610-2620. [CrossRef]

29. Behzadi, A.; Habibollahzade, A.; Ahmadi, P.; Gholamian, E.; Houshfar, E. Multi-objective design optimization of a solar based system for electricity, cooling, and hydrogen production. Energy 2019, 169, 696-709. [CrossRef]

30. Moaleman, A.; Kasaeian, A.; Aramesh, M.; Mahian, O.; Sahota, L.; Tiwari, G.N. Simulation of the performance of a solar concentrating photovoltaic-thermal collector, applied in a combined cooling heating and power generation system. Energy Convers. Manag. 2018, 160, 191-208. [CrossRef]

31. Cavalcanti, E.J.C. Exergoeconomic and exergoenvironmental analyses of an integrated solar combined cycle system. Renew. Sustain. Energy Rev. 2017, 67, 507-519. [CrossRef]

32. Ishaq, H.; Dincer, I.; Naterer, G. Development and assessment of a solar, wind and hydrogen hybrid trigeneration system. Int. J. Hydrog. Energy 2018, 43, 23148-23160. [CrossRef]

33. Yousefizadeh Dibazar, S.; Salehi, G.; Davarpanah, A. Comparison of Exergy and Advanced Exergy Analysis in Three Different Organic Rankine Cycles. Processes 2020, 8, 586. [CrossRef]

34. Darvish, K.; Ehyaei, M.; Atabi, F.; Rosen, M. Selection of optimum working fluid for organic Rankine cycles by exergy and exergy-economic analyses. Sustainability 2015, 7, 15362-15383. [CrossRef]

35. Kajurek, J.; Rusowicz, A.; Grzebielec, A.; Bujalski, W.; Futyma, K.; Rudowicz, Z. Selection of refrigerants for a modified organic Rankine cycle. Energy 2019, 168, 1-8. [CrossRef]

36. Zinet, M.; Rulliere, R.; Haberschill, P. A numerical model for the dynamic simulation of a recirculation single-effect absorption chiller. Energy Convers. Manag. 2012, 62, 51-63. [CrossRef]

37. Bellos, E.; Tzivanidis, C. Parametric analysis and optimization of a solar driven trigeneration system based on ORC and absorption heat pump. J. Clean. Prod. 2017, 161, 493-509. [CrossRef]

38. Yang, J.; Li, J.; Yang, Z.; Duan, Y. Thermodynamic analysis and optimization of a solar organic Rankine cycle operating with stable output. Energy Convers. Manag. 2019, 187, 459-471. [CrossRef]

39. Li, Z.X.; Ehyaei, M.A.; Kasmaei, H.K.; Ahmadi, A.; Costa, V. Thermodynamic modeling of a novel solar powered quad generation system to meet electrical and thermal loads of residential building and syngas production. Energy Convers. Manag. 2019, 199, 111982. [CrossRef]

40. Powell, W.R. An analytical expression for the average output power of a wind machine. Sol. Energy 1981, 26, 77-80. [CrossRef]

41. Akbari, R.; Ehyaei, M.A.; Shavvon, R.S. Optimization of Solar Rankine Cycle by Exergy Analysis and Genetic Algorithm. Int.J. Energy Power Eng. 2019, 13, 630-637.

42. Ghasemian, E.; Ehyaei, M. Evaluation and optimization of organic Rankine cycle (ORC) with algorithms NSGA-II, MOPSO, and MOEA for eight coolant fluids. Int. J. Energy Environ. Eng. 2018, 9, 39-57. [CrossRef]

43. Shirmohammadi, R.; Aslani, A.; Ghasempour, R.; Romeo, L.M. $\mathrm{CO}_{2}$ utilization via integration of an industrial post-combustion capture process with a urea plant: Process modelling and sensitivity analysis. Processes 2020, 8, 1144. [CrossRef] 
44. Li, C.H.; Zhu, X.J.; Cao, G.Y.; Sui, S.; Hu, M.R. Dynamic modeling and sizing optimization of stand-alone photovoltaic power systems usinghybrid energy storage technology. Renew. Energy 2009, 34, 815-826. [CrossRef]

45. Valizadeh, K.; Davarpanah, A. Design and construction of a micro-photo bioreactor in order to dairy wastewater treatment by micro-algae: Parametric study. Energy Sources Part A Recovery Util. Environ. Eff. 2020, 42, 611-624. [CrossRef]

46. Asgari, E.; Ehyaei, M.A. Exergy analysis and optimisation of a wind turbine using genetic and searching algorithms. Int. J. Exergy 2015, 16, 293-314. [CrossRef]

47. Ehyaei, M.A.; Ahmadi, A.; Rosen, M.A. Energy, exergy, economic and advanced and extended exergy analyses of a wind turbine. Energy Convers. Manag. 2019, 183, 369-381. [CrossRef]

48. Saidi, M.; Abbassi, A.; Ehyaei, M. Exergetic optimization of a PEM fuel cell for domestic hot water heater. J. Fuel Cell Sci. Technol. 2005, 2, 284-289. [CrossRef]

49. Bejan, A. Advanced Engineering Thermodynamics; John Wiley \& Sons: Hoboken, NJ, USA, 2016.

50. Dincer, I.; Rosen, M.A. Exergy: Energy, Environment and Sustainable Development; Newnes: New York, NY, USA, 2012.

51. Dinçer, I.; Midilli, A.; Kucuk, H. Progress in Exergy, Energy, and the Environment; Springer: Berlin/Heidelberg, Germany, 2014.

52. Yousefi, M.; Ehyaei, M.; Rosen, M.A. Optimizing a New Configuration of a Proton Exchange Membrane Fuel Cell Cycle with Burner and Reformer Through a Particle Swarm Optimization Algorithm for Residential Applications. J. Electrochem. Energy Convers. Storage 2019, 16, 040801. [CrossRef]

53. Zeinodini, M.; Aliehyaei, M. Energy, exergy, and economic analysis of a new triple-cycle power generation configuration and selection of the optimal working fluid. Mech. Ind. 2019, 20, 501. [CrossRef]

54. Shirmohammadi, R.; Gilani, N. Effectiveness enhancement and performance evaluation of indirect-direct evaporative cooling system for a wide variety of climates. Environ. Prog. Sustain. Energy 2019, 38, e13032. [CrossRef]

55. Bellos, E.; Pavlovic, S.; Stefanovic, V.; Tzivanidis, C.; Nakomcic-Smaradgakis, B.B. Parametric analysis and yearly performance of a trigeneration system driven by solar-dish collectors. Int. J. Energy Res. 2019, 43, 1534-1546. [CrossRef]

56. Tzivanidis, C.; Bellos, E.; Antonopoulos, K.A. Energetic and financial investigation of a stand-alone solar-thermal Organic Rankine Cycle power plant. Energy Convers. Manag. 2016, 126, 421-433. [CrossRef]

57. Alshammari, F.; Karvountzis-Kontakiotis, A.; Pesyridis, A.; Usman, M. Expander Technologies for Automotive Engine Organic Rankine Cycle Applications. Energies 2018, 11, 1905. [CrossRef]

58. Lecompte, S.; Huisseune, H.; van den Broek, M.; de Schampheleire, S.; de Paepe, M. Part load based thermo-economic optimization of the Organic Rankine Cycle (ORC) applied to a combined heat and power (CHP) system. Appl. Energy 2013, 111, 871-881. [CrossRef]

59. Quoilin, S.; Declaye, S.; Tchanche, B.F.; Lemort, V. Thermo-economic optimization of waste heat recovery Organic Rankine Cycles. Appl. Therm. Eng. 2011, 31, 2885-2893. [CrossRef]

60. Schöpfer, M.D. Absorption Chillers: Their Feasibility in District Heating Networks and Comparison to Alternative Technologies. Master's Thesis, Master of Science Degree in Energy Engineering and Management. Technical University of Lisbon, Lisbon, Portugal, 2015; p. 98.

61. Wulf, C.; Linßen, J.; Zapp, P. Review of power-to-gas projects in Europe. Energy Procedia 2018, 155, 367-378. [CrossRef]

62. Baier, J.; Schneider, G.; Heel, A. A Cost Estimation for $\mathrm{CO}_{2}$ Reduction and Reuse by Methanation from Cement Industry Sources in Switzerland. Front. Energy Res. 2018, 6, 5. [CrossRef]

63. Bellos, E.; Tzivanidis, C.; Symeou, C.; Antonopoulos, K.A. Energetic, exergetic and financial evaluation of a solar driven absorption chiller-A dynamic approach. Energy Convers. Manag. 2017, 137, 34-48. [CrossRef]

64. Ratlamwala, T.A.; Dincer, I.; Gadalla, M.A. Comparative environmental impact and sustainability assessments of hydrogen and cooling production systems. In Causes, Impacts and Solutions to Global Warming; Springer: Berlin/Heidelberg, Germany, 2013; pp. 389-408.

65. Ratlamwala, T.A.; Dincer, I.; Reddy, B.V. Exergetic and Environmental Impact Assessment of an Integrated System for Utilization of Excess Power from Thermal Power Plant. In Causes, Impacts and Solutions to Global Warming; Springer: Berlin/Heidelberg, Germany, 2013; pp. 803-824. 
66. Midilli, A.; Dincer, I. Development of some exergetic parameters for PEM fuel cells for measuring environmental impact and sustainability. Int. J. Hydrog. Energy 2009, 34, 3858-3872. [CrossRef]

67. Nakomčić-smaragdakis, B.B.; Dragutinović, N.G. Hybrid renewable energy system application for electricity and heat supply of a residential building. Therm. Sci. 2016, 20, 695-706. [CrossRef]

68. Pavlović, S.R.; Bellos, E.A.; Stefanović, V.P.; Tzivanidis, C.; Stamenković, Z.M. Design, simulation, and optimization of a solar dish collector with spiral-coil thermal absorber. Therm. Sci. 2016, 20, 1387-1397. [CrossRef]

69. Pavlovic, S.; Daabo, A.M.; Bellos, E.; Stefanovic, V.; Mahmoud, S.; Al-Dadah, R.K. Experimental and numerical investigation on the optical and thermal performance of solar parabolic dish and corrugated spiral cavity receiver. J. Clean. Prod. 2017, 150, 75-92. [CrossRef]

70. Pavlovic, S.; Bellos, E.; le Roux, W.G.; Stefanovic, V.; Tzivanidis, C. Experimental investigation and parametric analysis of a solar thermal dish collector with spiral absorber. Appl. Therm. Eng. 2017, 121, 126-135. [CrossRef]

71. Al-Mousawi, F.N.; Al-Dadah, R.; Mahmoud, S. Integrated adsorption-ORC system: Comparative study of four scenarios to generate cooling and power simultaneously. Appl. Therm. Eng. 2017, 114, 1038-1052. [CrossRef]

72. Al-Tahaineh, M.F.H.; Al-Rashdan, M. Exergy Analysis of a Single-Effect Water-Lithium Bromide Absorption Chiller Powered by Waste Energy Source for Different Cooling Capacities. Energy Power 2013, 3, 106-118.

73. Gorjian, T.T.H.S.; Ghobadian, B. Estimation of mean monthly and hourly global solar radiation on surfaces tracking the sun. In Proceedings of the 2012 Second Iranian Conference on Renewable Energy and Distributed Generation, Tehran, Iran, 6-8 March 2012; pp. 172-177.

74. Oberkampf, W.L.; DeLand, S.M.; Rutherford, B.M.; Diegert, K.V.; Alvin, K.F. Error and uncertainty in modeling and simulation. Reliab. Eng. Syst. Saf. 2002, 75, 333-357. [CrossRef]

75. Chwoła, T.; Spietz, T.; Więcław-Solny, L.; Tatarczuk, A.; Krótki, A.; Dobras, S.; Wilk, A.; Tchórz, J.; Stec, M.; Zdeb, J. Pilot plant initial results for the methanation process using $\mathrm{CO}_{2}$ from amine scrubbing at the Łaziska power plant in Poland. Fuel 2020, 263, 116804. [CrossRef]

76. Duffie, J.A.; Beckman, W.A. Solar Engineering of Thermal Processes; John Wiley \& Sons: Hoboken, NJ, USA, 2013.

77. Johnson, G.L. Wind Energy Systems; Citeseer: Gaithersburg, MD, USA, 2006.

78. Justus, C.G. Winds and Wind System Performance, Research Supported by the National Science Foundation and Energy Research and Development Administration; Franklin Institute Press: Philadelphia, PA, USA, 1978; p. 120.

Publisher's Note: MDPI stays neutral with regard to jurisdictional claims in published maps and institutional affiliations.

(C) 2020 by the authors. Licensee MDPI, Basel, Switzerland. This article is an open access article distributed under the terms and conditions of the Creative Commons Attribution (CC BY) license (http://creativecommons.org/licenses/by/4.0/). 